\title{
Summary of the fossil record of megalopteran and megalopteran-like larvae, with a report of new specimens
}

\author{
Viktor Baranov, Carolin Haug, Martin Fowler, Uwe Kaulfuss, \\ Patrick Müller \& JoAchim T. HaUg
}

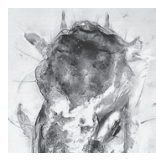

\begin{abstract}
Megaloptera is one of the smaller (about 400 modern species) monophyletic ingroups of Holometabola, including fishflies, dobsonflies and alderflies. All these are united by a very similar morphology, a distinct merolimnic lifecycle (aquatic larva, terrestrial pupa and adult) and by the short lifespan of the winged adults. Megaloptera is generally considered to be sister group to Neuroptera within Neuropterida. Unfortunately, the fossil record of the group is extremely scarce. Here we review the fossil record of megalopteran larvae; due to the long-lasting larval phase, one could argue that this is, in fact, the life phase with the largest ecological impact. Larvae of megalopterans are even rarer in the fossil record. Interestingly, many known larvae are preserved in amber, despite their aquatic lifestyle. Moreover, we report new specimens, including a fossil from the Miocene Foulden Maar of New Zealand, the Eocene Green River Formation, as well as different specimens preserved in amber from the Cretaceous of Myanmar. The New Zealand specimen resembles larvae of Sialidae. The Green River specimen could be a representative of Sialidae. A larger, partly incomplete amber specimen could be a representative of Corydalidae. Several small amber specimens resemble early larval stages of Chauliodinae, but also differ in important aspects. We discuss what the scarce fossil record of megalopteran larvae can tell us about their palaeo-biology and environment. - Key words: Megaloptera; Myanmar amber, Foulden Maar, Green River, Eocene, Cretaceous.
\end{abstract}

Baranov, V., Haug, C., Fowler, M., Kaulfuss, U., Müller, P. \& Haug, J.T. 2022. Summary of the fossil record of megalopteran and megalopteran-like larvae, with a report of new specimens. Bulletin of Geosciences 97(1), 89-108 (10 figures). Czech Geological Survey, Prague. ISSN 1214-1119. Manuscript received July 27, 2021; accepted in revised form December 13, 2021; published online January 23, 2022; issued January 23, 2022.

Viktor Baranov, Faculty of Biology, LMU Munich, Großhaderner Str. 2, 82152 Planegg-Martinsried, Germany; baranow@biologie.uni-muenchen.de - Carolin Haug \& Joachim T. Haug, Faculty of Biology, LMU Munich, Großhaderner Str. 2, 82152, Planegg-Martinsried, Germany \& GeoBio-Center at LMU, Richard-Wagner-Str. 10, 80333 München, Germany - Martin J.F. Fowler, Les Rocquettes, Orchard Road, South Wonston, Winchester, Hampshire, SO21 3EX, United Kingdom • Uwe Kaulfuss, Department of Animal Evolution and Biodiversity, University of Göttingen, Untere Karspüle 2, 37073 Göttingen, Germany • Patrick Müller, Amber Study Group, clo GeologicalPalaeontological Museum of the University of Hamburg, Bundesstraße 55, 20146 Hamburg, Germany • Joachim T. Haug, Faculty of Biology, LMU Munich, Großhaderner Str. 2, 82152, Planegg-Martinsried, Germany \& GeoBioCenter at LMU, Richard-Wagner-Str. 10, 80333 München, Germany

Megaloptera is a rather species-poor ingroup of Holometabola. Its representatives include fishflies, alderflies and dobsonflies (Cover \& Resh 2008, Cover \& Bogan 2015, Heckman 2017). About 400 species of Megaloptera are known from the extant fauna (Cover \& Resh 2008). Extant megalopterans are generally differentiated into two major ingroups: Sialidae Leach, 1815 and Corydalidae Van der Weele, 1910 (Cover \& Resh 2008). All adult megalopterans have prominently equal-sized wings. Adult dobsonflies (Corydalinae, ingroup of Corydalidae) are conspicuous by their huge protruding mandibles, probably involved in sexual (female) choice, as well as a very large body size and wingspan, reaching $180 \mathrm{~mm}$ (Cao \& Liu 2013, Heckman 2017).

The monophyly of Megaloptera was brought into question several times in recent years based on molecular (Winterton et al. 2010) and morphological data (Beutel \& Friedrich 2008, Beutel et al. 2013). Yet, most of the contemporary sources do agree that Sialidae + Corydalidae is a monophyletic group, i.e. Megaloptera, which is either the sister group to Neuroptera + Raphidioptera or only to the former (Wang \& Zhang 2010, Liu et al. 2012, Wang et al. 2017, Zhao et al. 2017, Engel et al. 2018, Winterton et al. 2018, Haug et al. 2020a). All three groups together, 
Megaloptera, Raphidioptera (snake flies) and Neuroptera (lacewings), form the larger group Neuropterida (Engel et al. 2018, Haug et al. 2020b).

Megalopterans spend most of their lifetime in their larval form (for ambiguities of the term, see Haug 2020), up to five years, but only few days or, at most, weeks as adults (Cover \& Bogan 2015). During their larval phase they progress through up to 12 larval instars or stages (Evans 1972, Cover \& Bogan 2015). Some megalopteran larvae are among the largest forms of Insecta with aquatic larvae (merolimnic) in the world. In particular, larvae of the group Corydalus Latreille, 1802, commonly known as "hellgrammites", reach up to $80 \mathrm{~mm}$ in length (Cover \& Bogan 2015).

In general, megalopteran larvae play an important role as predators in modern freshwater communities. This role makes them very sensitive to the general health of a biological community (Evans 1972, Stewart et al. 1973). Indeed, megalopteran larvae are generally considered to be important ecological status indicators (Heckman 2017). Such high habitat specificity makes records of fossil megalopteran larvae very valuable for direct palaeohabitat/palaeo-climatic inferences, as in insect groups with aquatic larvae inferring larval ecology based on corresponding adults can lead to confusion (see discussion in Baranov et al. 2019a).

The fossil record of adult megalopterans is relatively scarce, with fewer than 50 individual occurrences reported in the literature (Rasnitsyn \& Quicke 2002, Grimaldi \& Engel 2005, Wichard et al. 2009, Zhao et al. 2019). The geological history of the group Megaloptera spans around $200 \mathrm{Ma}$ into the past, with the alderfly Dobbertinia reticulata Handlirsch, 1920 known from the lower Jurassic of Germany (Ansorge 2001) being the oldest record.

The fossil record of megalopteran larvae is, likewise, quite scarce. While there are only a few specimens, many of them have been repetitively re-figured. Here, we review the fossil record of megalopteran larvae, report new forms and discuss what type of conclusions can be drawn from such a scarce fossil record.

\section{Material and methods}

Material. - Seven specimens were directly documented for the present study. One specimen comes from the Eocene Green River Formation. This specimen was acquired by MF from The Fossil Dude (https://www.thefossildude. $\mathrm{com} /$ ) and is now deposited in the PED research collection (Germany, Munich, Ludwig-MaximiliansUniversität München, Palaeo-Evo-Devo Research Group Collection of Arthropods) under the accession number PED 0466.
Five specimens are preserved in amber from Myanmar. Three of them were acquired by PM (BUB 2199, BUB 3190, BUB 3356) and are currently part of the Staatliche Naturwissenschaftliche Sammlung Bayerns-Bayerische Staatssammlung für Paläontologie und Geologie München (SNSB-BSPG 2020 XCIII 16, SNSB-BSPG 2021 XII 5, SNSB-BSPG 2021 XII 6). The two other specimens were legally acquired via the platform eBay by JTH from the trader burmite-miner (see part of the discussion on amber trade from Myanmar e.g. Haug et al. 2020c). Both are also part of the PED research collection (PED 0335, PED 0346).

The geological context of Myanmar amber (Cruickshank \& Ko 2003, Yu et al. 2019) and of the Green River Formation (Cole \& Picard 1978; Grande 1984, 2013; Swanson et al. 2021) has been explained in detail in various previous works.

A further specimen was collected by UK at the Foulden Maar Fossil-Lagerstätte in southern New Zealand. It is housed in the collections of Department of Geology, University of Otago under catalogue number OU45249.

Foulden Maar is somewhat less known internationally, therefore we will provide a short description here. The New Zealand specimen comes from lacustrine diatomite accumulated over 130,000 years in a small, isolated maar lake of earliest Miocene age (23 My), as determined by palynology and radiometric dating of associated volcanic rocks. Freshwater conditions are indicated by algae, sponges, fish and merolimnic insects (mainly fly pupae) in the same deposit. It is the sole megalopteran specimen from Foulden Maar and the first fossil representative of this group from New Zealand. The geological setting, age and fossil biota of Foulden Maar are described in Lindqvist \& Lee (2009), Mildenhall et al. (2014), Lee et al. (2016), and Kaulfuss (2017).

Documentation methods. - The specimens were documented on a Keyence VHX 6000 digital microscope. Amber specimens were covered with a cover slip and demineralised water above the area of the specimen of interest. Each specimen was documented with a stack of images of shifting focus. The stack was fused to a single sharp image. Specimens were documented with several stacks of adjacent image details and stitched to panoramas (Haug et al. 2011, Hörnig et al. 2016). In most cases, each image was additionally recorded with several exposure times (HDR function) (Haug et al. 2013, Baranov et al. 2019b). Each specimen was recorded with unpolarised ring light illumination and cross-polarised co-axial illumination (Haug et al. 2013, Baranov et al. 2019b). The image providing the better contrast was used here. If both images showed complementary details, both are shown. Images were processed with the microscope software and further 


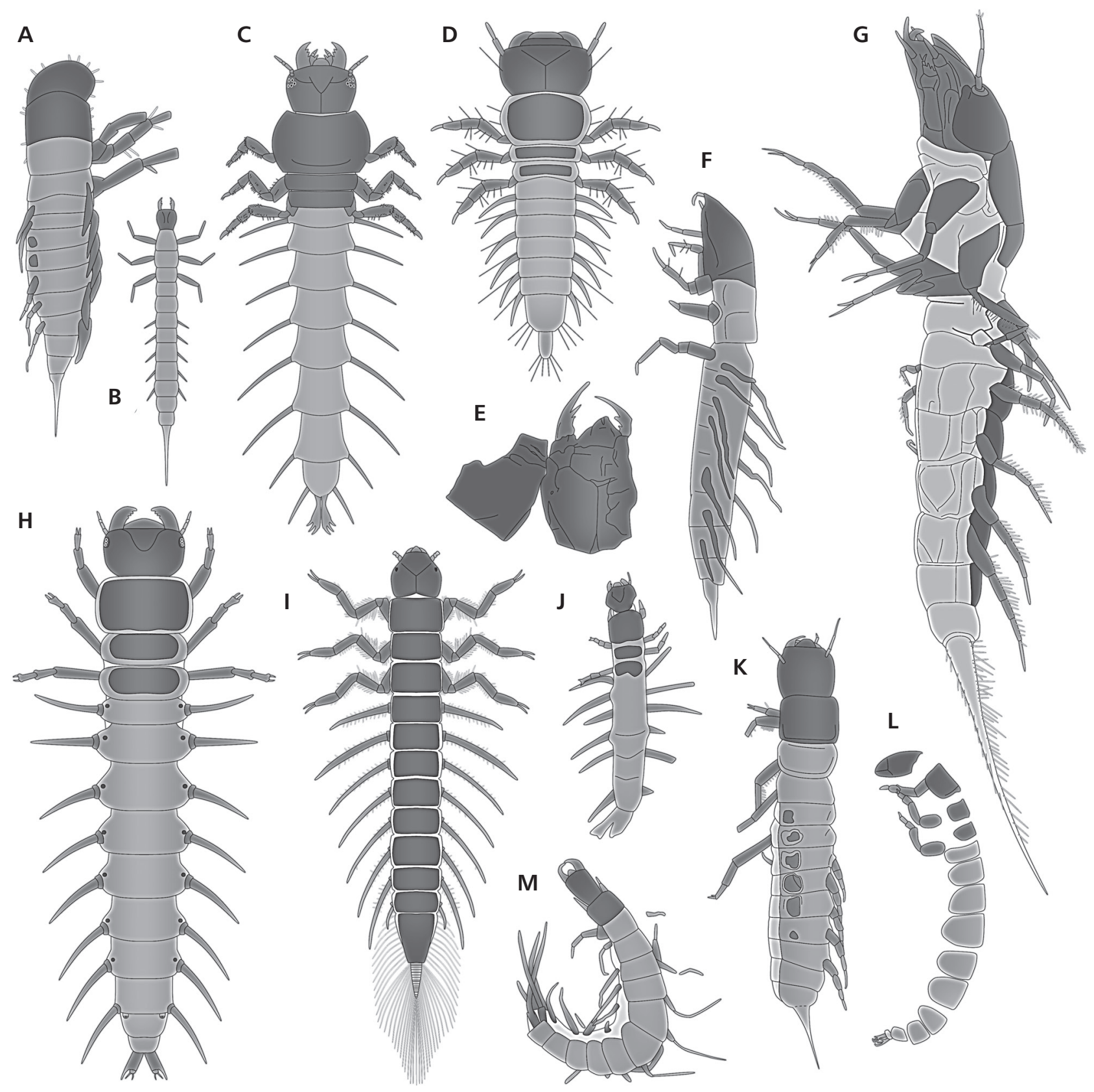

Figure 1. Fossils with megalopteran-larva-type morphology from the literature. A - type 1 (simplified from Wichard \& Weitschat 1996). B - type 2 (composite restoration based on Illies 1967). C - type 3 (composite restoration based on Ponomarenko 1976). D - type 4 (idealised restoration based on Ponomarenko 1976). E - type 5 (simplified from Nel 1991). F - type 6 (simplified from Wichard \& Weitschat (2004). G - type 7 (simplified from Wichard et al. 2009). H - type 8 (simplified from Wang \& Zhang 2010). I - type 9 (idealised restoration based on Ponomarenko 2012 ). J - type 10 (simplified from Liu et al. 2012). K - type 11 (simplified from Gröhn 2015). L - type 12 (simplified from Zhao et al. 2019). M - possible megalopteran larva (simplified from Xia et al. 2015). Images not to scale, size of images correlates to availability of details, specimens with more details are shown larger.

optimised in Adobe Photoshop CS2. Drawings were prepared in Adobe Illustrator CS2.

Morphological terminology. - The morphological terminology largely follows New \& Theischinger (1993), Cover \& Bogan (2015) and Heckman (2017). However, to enhance the understandability for non-experts, we amended some of the special morphological terms with more general terms. As Insecta is an accepted ingroup of Crustacea s.l., crustacean-terms given in square brackets were necessary to provide wider frame correspondence (Baranov et al. 2019a). 


\section{Results}

\section{Fossils with megalopteran-larva-type morphology}

All occurrences of fossil megalopteran larvae in the literature are listed chronologically. Cases in which the same specimen has been re-figured are also included chronologically with reference to the original occurrence. While this includes a certain redundancy, it should represent the most complete way of cross-referencing, avoiding interpreting the same specimens as two independent occurrences.

(1) Weidner (1958) reported a megalopteran larva (type 1) preserved in Eocene Baltic amber (Fig. 1A). The specimen was apparently re-figured in Wichard \& Weitschat (1996) and Weitschat \& Wichard (1998, 2002). Note: this publication was not seen in original version by the authors, but it is cited indirectly.

(2) Illies (1967) reported numerous fossil larvae (type 2) of an alderfly (Sialidae) from the Pliocene of Germany (Willershausen) (Fig. 1B). These larvae (Illies 1967: figs 1left, $2 \mathrm{a}-\mathrm{d}$ ) are among the most abundant animal fossils in the deposit. They were interpreted as larvae of the species Sialis strausi, which has been described from the same deposit based on isolated wings. The preservation is not very good, the degree of details remains poor, yet the mandibles in combination with a terminal filament clearly demonstrate that these are alderfly larvae.

(3) Coope (1970) reported fragments of mandibles of megalopteran larvae in Quaternary sediments. Unfortunately, the fragments were only mentioned in the text, but not figured. This seems to be the case also for some older literature reports (references therein). Hence such Quaternary specimens are not further considered here.

(4) Ponomarenko (1976) reported two different types of fossil megalopteran larvae from the Cretaceous. One type (type 3) was identified as representing a larva of Corydalidae and ascribed to Cretochaulus lacustris. In total, 16 specimens, representing different larval instars were reported (Ponomarenko 1976: figs 3-5, 7) from Baissa River in Transbaikalia. No full restoration was offered, only one strongly based on extant counterparts (Ponomarenko 1976: fig. 2). We have chosen here to assemble a composite restoration (Fig. 1C). One specimen was re-figured in Ponomarenko (in Rasnitsyn \& Quicke 2002).

The other type (type 4) was, likewise, identified as representing a larva of Corydalidae and ascribed to Chauliosialis sukatshevae (Ponomarenko 1976: figs 6, 8). The single known specimen is preserved in Taymyr am- ber. We provide a simplified restoration (Fig. 1D) based on the interpretative drawing in Ponomarenko (1976: fig. 6).

(5) Nel $(1991$ : figs 18, 19) reported remains of a megalopteran larva from the Miocene-Pliocene of France (type 5). The specimen is rather incomplete, mostly the head capsule and mandibles are preserved (Fig. 1E).

(6) Wichard \& Weitschat (1996) re-figured the type 1 specimen, i.e. the specimen from Weidner (1958).

(7) Weitschat \& Wichard (1998) re-figured the type 1 specimen, i.e. the specimen from Weidner (1958). Note: this publication was not seen in original version by the authors, but is cited indirectly.

(8) Weitschat \& Wichard (2002: fig. 51c) re-figured the type 1 specimen, i.e. the specimen from Weidner (1958).

(9) Ponomarenko in Rasnitsyn \& Quicke (2002: fig. 247) re-figured a specimen of type 3 . Also, the reconstruction drawing strongly based on extant counterparts was refigured (Rasnitsyn \& Quicke (2002: fig. 244).

(10) Wichard \& Weitschat (2004) figured a new specimen (type 6) preserved in Eocene Baltic amber (Fig. 1F). The specimen was re-figured in Wichard (2005), Wichard \& Engel (2006) and Wichard et al. (2009).

(11) Wichard (2005: fig. 23) re-figured the type 6 specimen, i.e. the specimen from Wichard \& Weitschat (2004).

(12) Wichard \& Engel (2006: fig. 1) re-figured the type 6 specimen, i.e. the specimen from Wichard \& Weitschat (2004).

(13) Wichard et al. (2009: fig. 06.01a, b, d) figured a new specimen (type 7) preserved in Eocene Baltic amber (simplified in Fig. 1G). The specimen was re-figured in Weitschat \& Wichard (2010). Wichard et al. (2009: fig. 06.01e) additionally re-figured the type 1 specimen, i.e. the specimen from Weidner (1958), and the type 6 specimen (Wichard et al. 2009: fig. 06.01c), i.e. the specimen from Wichard \& Weitschat (2004).

(14) Weitschat \& Wichard (2010: fig. 11d) re-figured the type 7 specimen, i.e. the specimen from Wichard et al. (2009).

(15) Wang \& Zhang (2010) reported a new type (type 8) of megalopteran larvae ascribed to the species Jurochaulides ponomarenkoi. In total three specimens were reported from the middle Jurassic of China (Wang \& Zhang 2010: 

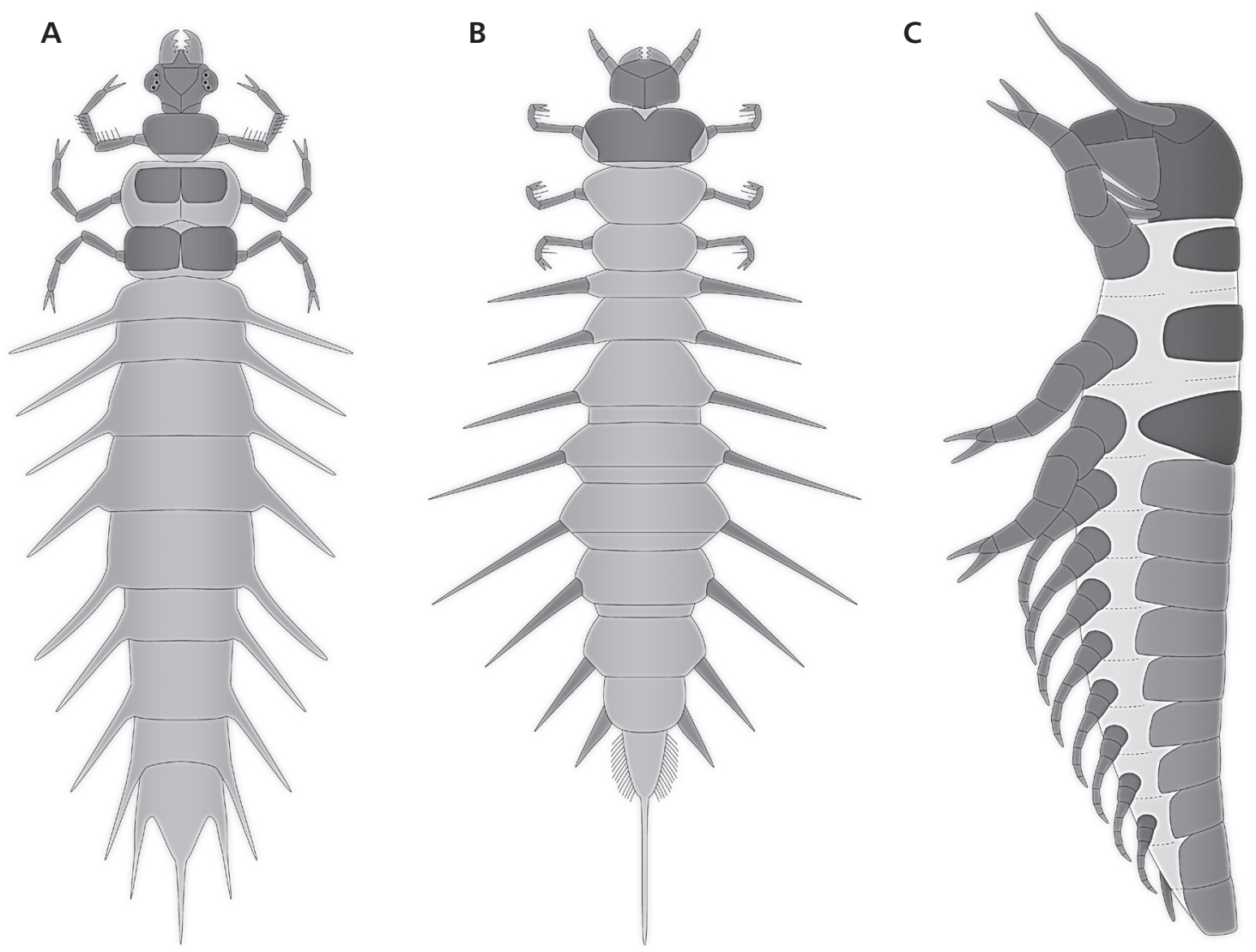

Figure 2. Fossils with certain characters resembling those of megalopteran larvae. A - Kargalarva permosialis (idealised restoration based on Prokin et al. 2019). B - Trialarva coburgensis (simplified from Prokin \& Bashkuev 2021). C - Srokalarva berthei (based on Haug et al. 2015). Not to scale.

figs 1-3). A restoration was provided as well (Wang \& Zhang 2010: fig. 4; simplified in Fig. 1H).

(16) Ponomarenko (2012: fig. 1, pl. 8) reported a new type (type 9) of megalopteran larva ascribed to the species Sharasialis fusiformis. The single known specimen came from the upper Jurassic, Shar-Teg, Mongolia. We provide a simplified restoration (Fig. 1I) based on the interpretive drawing in Ponomarenko (2012: fig. 1a).

(17) Liu et al. (2012) reported two new specimens of fossil megalopteran larvae, both from the middle Jurassic of China. The first specimen (Liu et al. (2012: fig. 1h-k) was ascribed to the species Eochauliodes striolatus (type 10; Fig. 1J). The second specimen was interpreted as another (fourth) specimen of Jurochauliodes ponomarenkoi (type 8).

(18) Gröhn (2015: p. 249, fig. 7681) reported a new specimen (type 11) of a fossil megalopteran larva preserved in Eocene Baltic amber (Fig. 1K).

(19) Zhao et al. (2019: figs 2, 3) reported a new specimen (type 12) of a fossil megalopteran larva from the Early Cretaceous, Yixian, China (Fig. 1L).

\section{Megalopteran-larva-like fossils}

Four additional fossils are listed here as they possess certain characters of megalopteran larvae. Yet, they clearly lack some key features of these larvae. All four are listed below, although not in strict chronological order as the ones above (Fig. 2A-C).

(20) Sharov (1953) reported a fossil that he interpreted as a larval stage of a megalopteran. The specimen was ascribed to the group Permosialis. This attribution was questioned subsequently (see discussion in Prokin et al. 2019 and references therein). The specimen was refigured in Ponomarenko in Rasnitsyn \& Quicke (2002: fig. 246, erroneously labelled as 236) and Prokin et al. (2019: fig. 2). The latter authors pointed out similarities of the specimen with beetles and megalopterans, but interpreted it as a species of Coleoptera, i.e. Kargalarva permosialis (Fig. 2A).

(21) Kukalová-Peck and co-authors (Kukalová-Peck \& Willmann 1990, Shear \& Kukalová-Peck 1990) repetitively reported on the presumed oldest holometabolan larva and suggested a relationship to the lineage of Antliophora. 


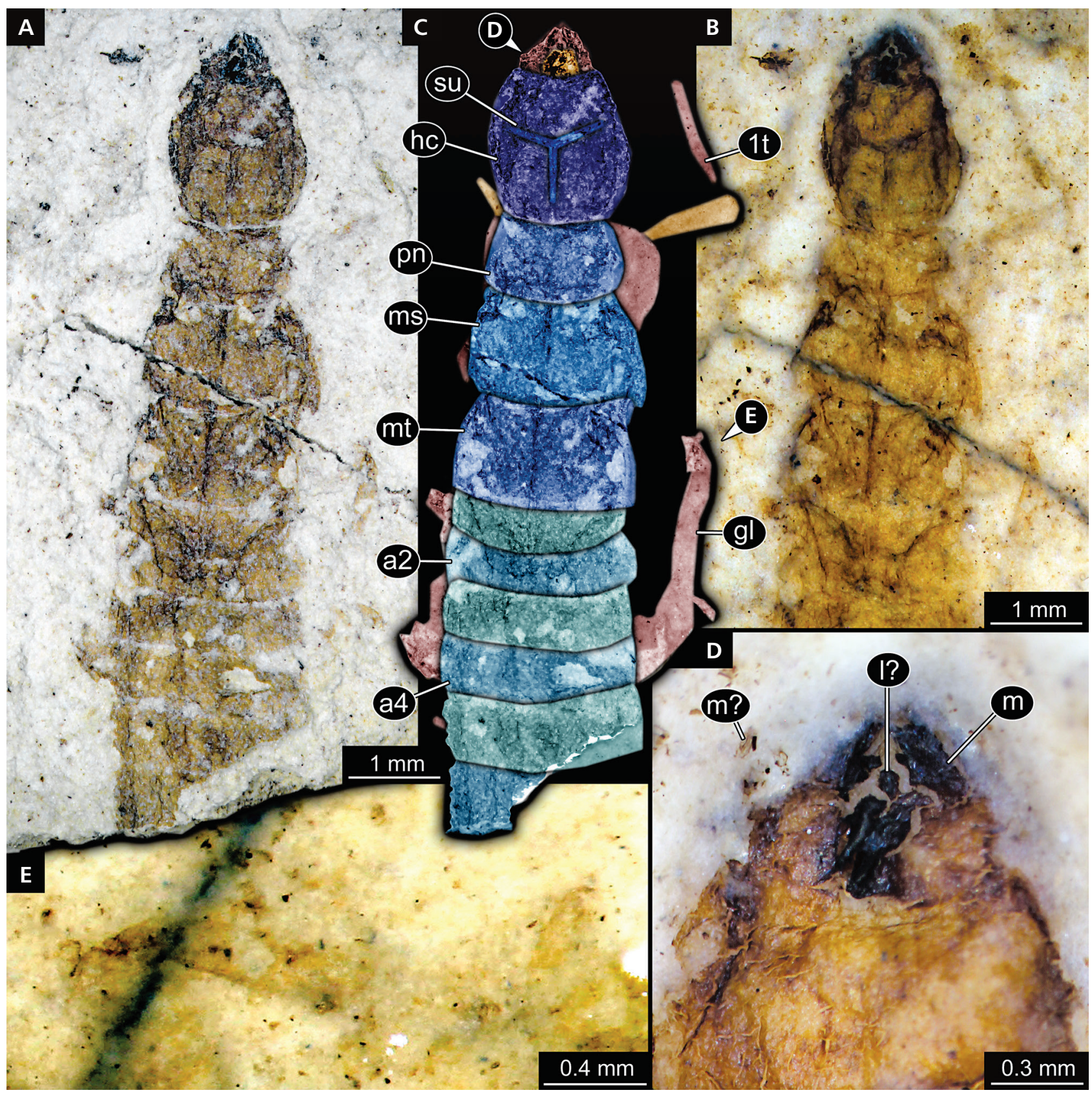

Figure 3. New morphotype 1 (OU45249), from the Miocene Foulden Maar. A - overview; B - overview photographed under ethanol; C - colourmarked; D - mouthparts; E - lateral gill. Abbreviations: 1? - possible labium; 1t - tarsomere 1; a2-a4-abdomen segments 2-4; gl - appendage of trunk/thorax segment 1 or possible leg elements; hc - head capsule; $\mathrm{m}$ - mandible; $\mathrm{m}$ ? - possible maxillary palp; ms - mesothorax; $\mathrm{mt}$ - metathorax; pn - pronotum; su - moulting suture.

Yet, this was heavily questioned, and the specimen was suggested to be a representative of Myriapoda (Willmann 1998). A re-investigation (Haug et al. 2015) supported an interpretation as a larval representative of Holometabola. Also, a possible closer relationship to Megaloptera was discussed (Fig. 2C).

(22) Xia et al. (2015, p. 085, lower figure) figured a specimen, preserved in amber from Myanmar, resembling a megalopteran larva in many aspects. Yet, the trunk end is not easily compatible with this interpretation (Fig. 1M). Unfortunately, many details are not accessible in the provided image.

(23) Prokin \& Bashkuev (2021: figs 1, 2) figured a specimen from the Triassic of Lower Franconia, southern Germany. The specimen, formally named as Trialarva coburgensis, is very similar to Kargalarva permosialis 
in overall morphology ( $c f$. Fig. 2B vs. 2A). The authors suggested that it might represent a larva of an early specialised beetle, but also mentioned some similarities to megalopteran larvae.

Further fossils formerly suggested to be megalopteran larvae, e.g. Mormolucoides articulatus or specimens of Coptoclavidae (e.g. see Ponomarenko 1976) are now generally accepted as representing beetles (Huber et al. 2003).

Haug et al. (2020b) reported an unusual larva in Myanmar amber. The larva combined morphological details known from beetle larvae, lacewing larvae, but also megalopteran larvae. Yet, the differences to known larvae of Megaloptera are even stronger than to the megalopteran-like larvae reported by Sharov (1953) and Prokin \& Bashkuev (2021). The larva reported by Haug et al. (2020b), for example, has a forward protruding, beak-like mouth cone, which is very different from the cutting-grinding mandibles seen in megalopteran larvae, but also other megalopteran-like larvae. Therefore, the specimen is not further considered here.

\section{New fossils with megalopteran-larva-type morphology}

(24) New morphotype 1 (University of Otago catalogue number OU45249) (Fig. 3A-E). Specimen preserved on a slab of diatomite matrix from Miocene Foulden Maar, New Zealand. Only the part is available, the counterpart was not found. The specimen is only partially preserved, with the rear part of the body (from abdomen segment

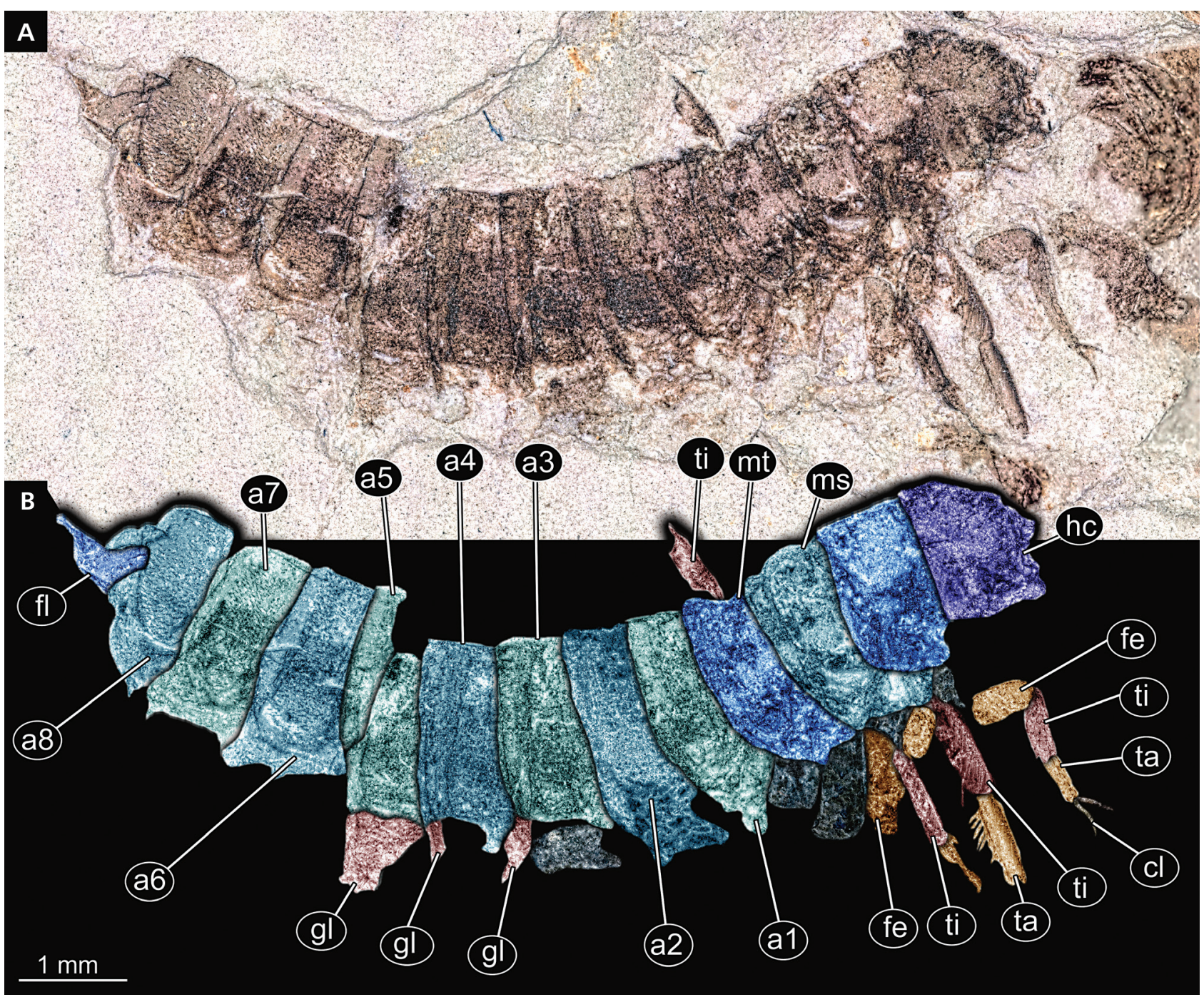

Figure 4. New morphotype 2 (PED 0466), from the Eocene Green River Formation. A - overview; B - same as A, colour-marked. Abbreviations: a1-a8 - abdomen segments 1-8; cl - tarsal claws; fe - femur; fl - possible terminal filament; gl - gill; hc - head capsule; ms - mesothorax; $\mathrm{mt}$ - metathorax; ta - tarsus; ti - tibia. 


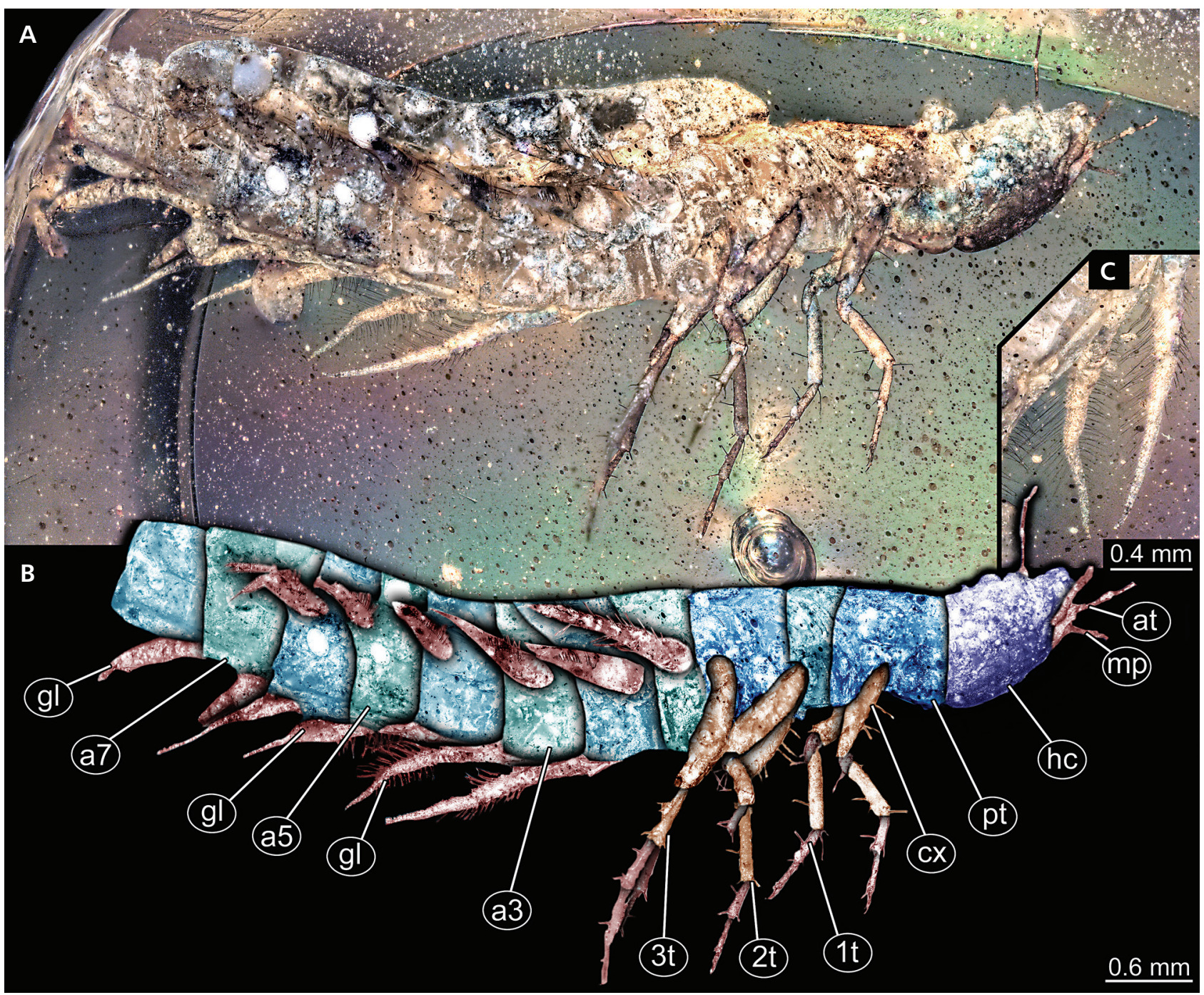

Figure 5. New morphotype 3; specimen (SNSB-BSPG 2020 XCIII 16, formerly BUB 2199) in a piece of amber from Myanmar. A - habitus; $\mathrm{B}$ - habitus, colour-marked; $\mathrm{C}$ - gills on abdomen segments 2 and 3. Abbreviations: $1 \mathrm{t}-3 \mathrm{t}$ - appendage of trunk/thorax segment 1-3; a1-a7 - abdomen segments 1-7; at - antenna; cx - coxa; gl - gill; hc - head capsule; $\mathrm{mp}$ - maxillary palp; $\mathrm{pt}$ - prothorax.

6 onwards) missing. Length of the preserved part is $8.9 \mathrm{~mm}$. Body largely intact (not disarticulated), with at least left foreleg and one of the lateral gills visible (Fig. 3E). Mouthparts are largely well preserved, with mandibles well visible in ventral aspect (Fig. 3D).

(25) New morphotype 2 (PED 0466). Specimen preserved on a slab of stone matrix from the Eocene Green River Formation. Only the part is available (it was sold to one of the authors, MF, as "Tipulidae larva", counterpart was not found). The specimen is about $13 \mathrm{~mm}$ long, with a moderate degree of overall preservation. The body appears largely intact (not disarticulated); certain parts of legs are very well preserved, with numerous setae still being well visible (Fig. 4). Head structures are almost entirely weathered away, or probably preserved on the absent counterpart.
The trunk appendages are well accessible up to the distal claws; they bear prominent setation, especially on the tarsus. The abdomen segments clearly bear protrusions, arising laterally, especially prominent on abdomen segments 3-5. Although incomplete, these structures are interpreted as gills. Terminally a smaller broken off structure is apparent.

(26) New morphotype 3 (SNSB-BSPG 2020 XCIII 16, formerly BUB 2199). Specimen preserved in a piece of amber from Myanmar. Overall, the specimen is well preserved, but the terminal end is not preserved (Fig. 5). The specimen is $7.4 \mathrm{~mm}$ long, visible in ventro-lateral and dorso-lateral view.

Trunk appendages are well-apparent. The coxae are unusually elongated. The posterior trunk segments (abdomen) bear prominent protrusions, arising laterally. 
These structures appear softer, elongate cone-shaped, and bear numerous setae (Fig. 5C). At least the anterior seven abdomen segments bear such structures.

(27) New morphotype 4. Represented by four specimens from Myanmar amber (PED 0335, PED 0346, SNSBBSPG 2021 XII 5, SNSB-BSPG 2021 XII 6; Figs 6-8). All four larvae are very small, $(0.3-4.0 \mathrm{~mm})$. Specimens are well preserved.

PED 0346 is well accessible in dorsal view (Fig. 6A-C). The anterior eight abdomen segments bear prominent protrusions, arising laterally, but slightly ventrally.
The protrusions are bipartite with a proximal part and an articulated distal part. The trunk end bears a pair of distinct structures; unclear if truly jointed, but at least set off by a fold (Fig. 6D). Each of these bear two prominent setae and one slightly curved claw-like spine.

PED 0335 is partly twisted, providing a dorsal view onto the head, but a ventral view on most parts of the trunk (Fig. 7A-C). It appears that a distinct sclerite is present on most of the trunk segments. It is restricted to the anterior region of the segment and the posterior rim is armed with setae and/or spines. Such a sclerite is clearly present on the mesothorax and metathorax. For the anterior abdomen

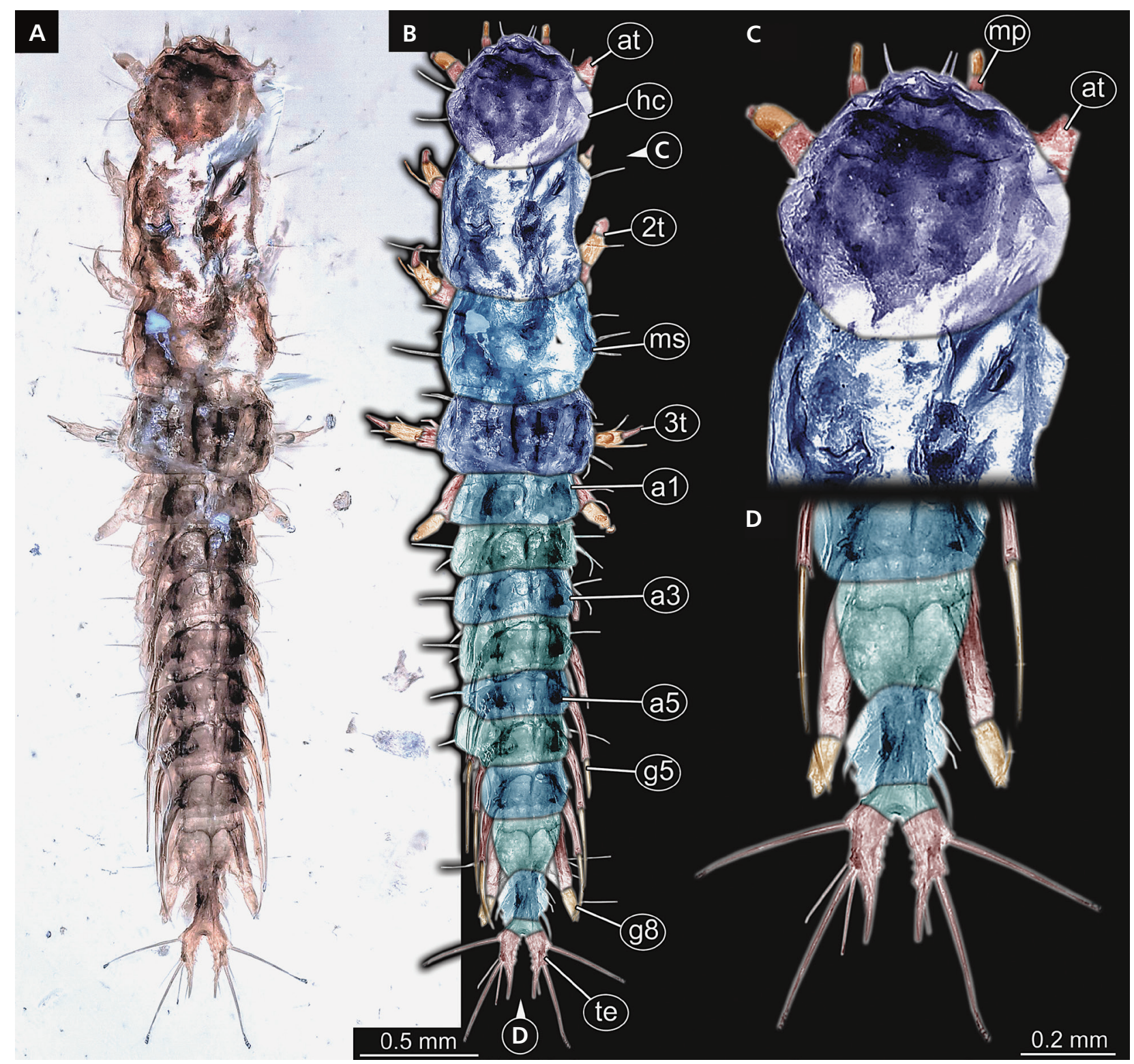

Figure 6. New morphotype 4; specimen (PED 0346) in a piece of amber from Myanmar. A - overview; B - same as A, colour-marked; C - head capsule, marked; D - trunk end. Abbreviations: $2 \mathrm{t}-3 \mathrm{t}$ - appendage of trunk/thorax segment 2-3; a1-a5 - abdomen segments 1-5; at - antenna; g5-g8 - gill of abdomen segments 5-8; hc - head capsule; mp - maxillary palp; ms - mesothorax; te - trunk end. 


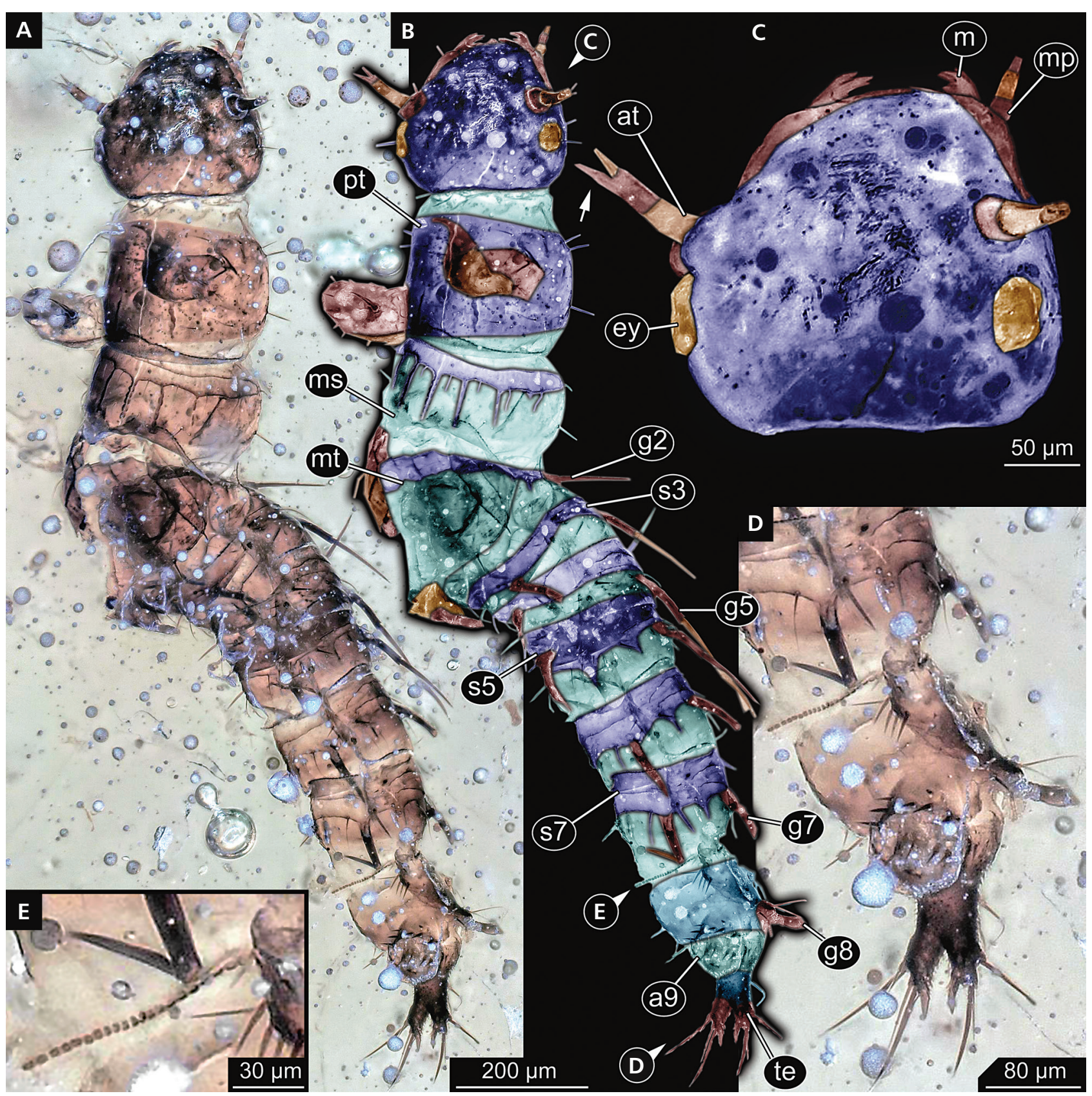

Figure 7. New morphotype 4; specimen (PED 0335) in a piece of amber for Myanmar. A - overview; B - same as A, colour-marked; C - head capsule, colour-marked; D - trunk end; E - possible thread of Cyanobacteria. Abbreviations: a9 - abdomen segment 9; at - antenna; g2-g8 - gill of abdomen segments 2-8; $\mathrm{mp}$ - maxillary palp; $\mathrm{ms}$ - mesothorax; $\mathrm{mt}$ - metathorax; $\mathrm{pt}$ - prothorax; s3-s7 - abdomen segment 3-7; te - trunk end.

segments this remains unclear as the specimen is partly folded in this region. Abdomen segments 3-7 again have such a sclerite. The protrusions appear to arise from the posterior border of the sclerites. The trunk end resembles that of PED 0346 (Fig. 7D).

SNSB-BSPG 2021 XII 5 is accessible in dorsal view, but partly concealed by cracks and bubbles. Still some structures are very similar to PED 0346 and PED 0335. Meso- and metathorax appear to bear a sclerite resembling those on the ventral side of PED 0335 also on the dorsal side (Fig. 8A). Again the trunk end resembles that of PED 0346 (Fig. 8B)

SNSB-BSPG 2021 XII 6 is extremely small, not many details are observable (Fig. 8C). Yet, also here the trunk end resembles that of PED 0346 (Fig. 8D).

(28) Additionally, we can report that more specimens seem to be present in collections of non-professional palaeontologists, further indicating that indeed megalopteran larva are more common, at least, in Baltic amber. 
As examples, images of specimens provided by Jonas Damzen are shown (Fig. 9).

\section{Discussion}

Why the new fossils can be megalopterans: diversification events

The new fossils show clear characters of megalopteran larvae, but some are more difficult to interpret due to missing details (e.g. the trunk end). We should therefore, before we discuss each of the new types in detail, consider some general aspects in how far these new fossils can indeed be megalopterans.

One such aspect is diversification time. It is well known that some lineages are relatively young and cannot be expected in fossil deposits of a certain age, or at least will be quite rare (see e.g. Haug \& Haug 2021 for fossil lepidopteran caterpillars).

Holometabolan fossils, in general, are known already from the Carboniferous (Nel et al. 2013), and neuropter-

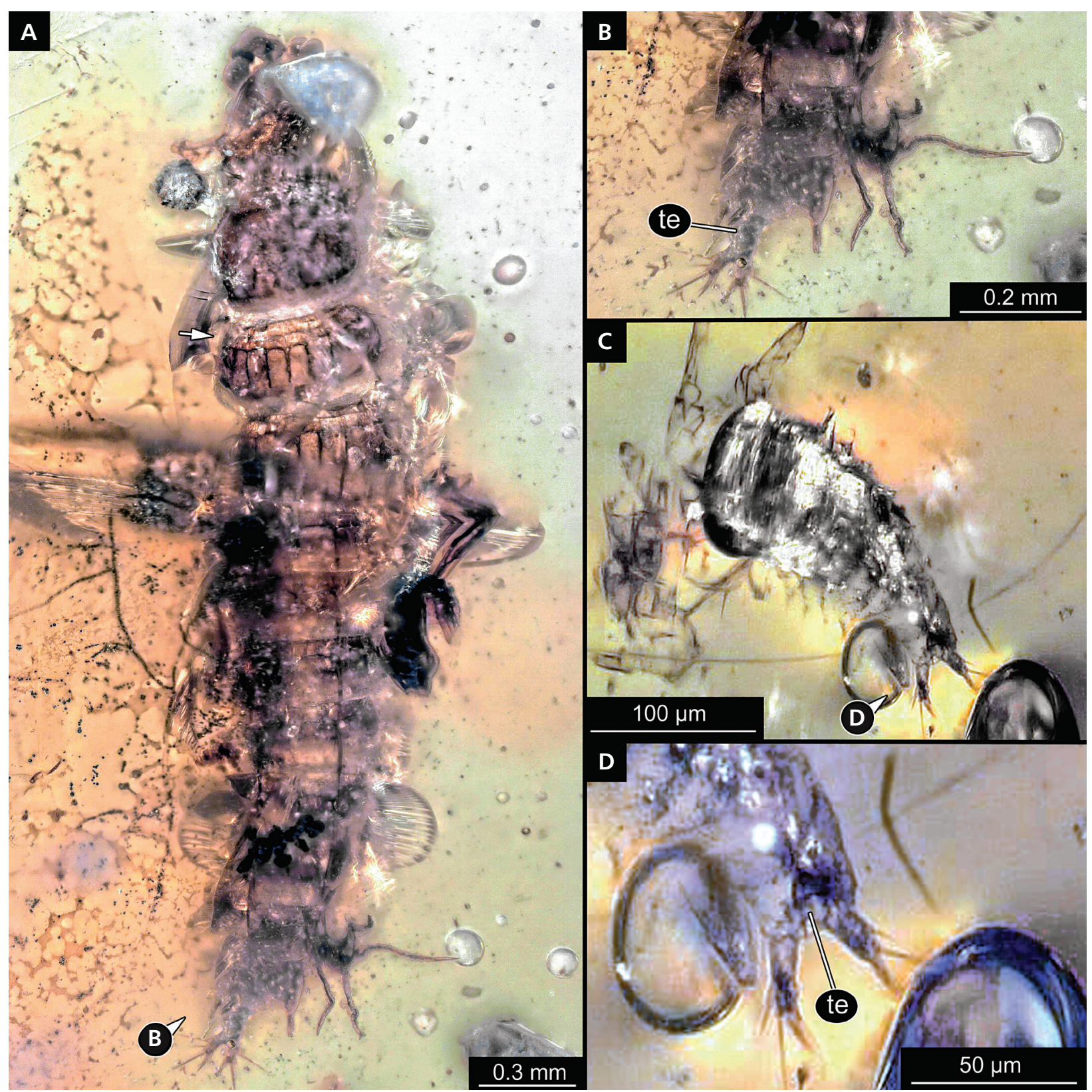

Figure 8. New morphotype 4. A, B - SNSB-BSPG 2021 XII 5, formerly BUB 3190; A - overview; B - trunk end. C, D - SNSB-BSPG 2021 XII 6, formerly BUB 3356; C - overview; D - trunk end. Abbreviation: te - trunk end. 


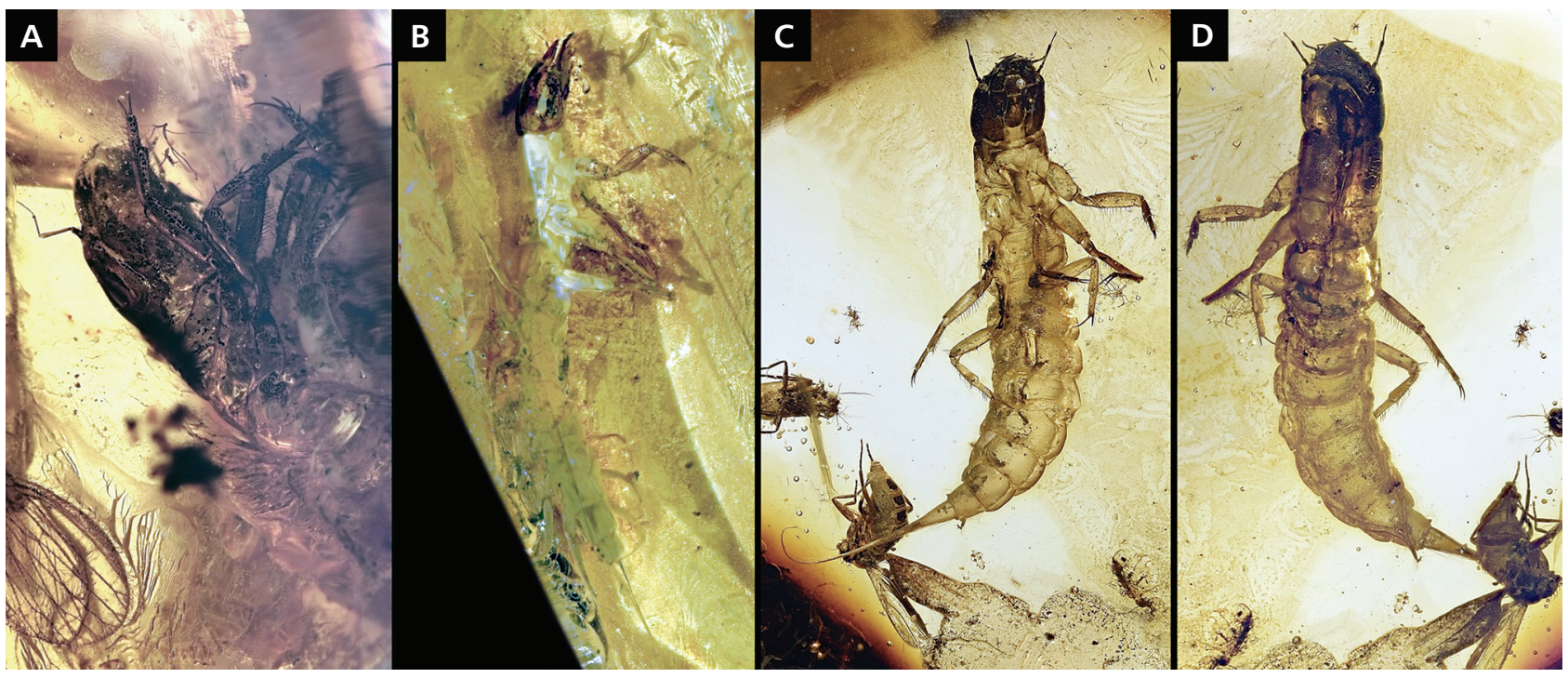

Figure 9. Examples of more fossil megalopteran larvae (Sialidae) in Baltic amber. Images provided by Jonas Damzen. Images not to scale.

idans are generally considered to have been part of the early diversification. The fossils from the Jurassic (type 8, Wang \& Zhang 2010; type 9, Ponomarenko 2012) furthermore demonstrate that the two main lineages, and the two larval morphotypes, were already present in the Jurassic. We therefore have to expect larvae of megalopterans in the younger deposits and especially in Myanmar amber as this Lagerstätte has provided us with such an enormous wealth of diversity (Ross 2019).

\section{Why the new fossils can be megalopterans: the problem of aquatic fossils in amber}

Especially for the amber specimens often the question is raised whether these can be aquatic organisms as they are preserved in a substance of terrestrial source. We will discuss the preservation windows for megalopteran larvae in more detail further below and show that there are indeed also "terrestrial moments" in the life of a megalopteran larva.

Yet, it needs to be emphasised that aquatic organisms and even marine faunal components are not impossible to be preserved in amber. Numerous examples can be found, including aquatic larvae of various lineages of Insecta (Wichard \& Weitschat 1996; Wichard 2005, 2017; Bechly \& Wichard 2008; Wichard et al. 2009; Sroka et al. 2018; Zhao et al. 2019; Gustafson et al. 2020; Schädel et al. 2020), aquatic (including marine) crustaceans (Coleman \& Myers 2001; Coleman 2004, 2006; Jażdżewski \& Kupryjanowicz 2010; Jażdżewski et al. 2014; SánchezGarcía et al. 2015; Serrano-Sánchez et al. 2015, 2016; Huys et al. 2016; Heard et al. 2018; Du et al. 2019; Schädel et al. 2019, 2021a, b), but also other marine faunal elements (Girard et al. 2008, Yu et al. 2019). Hence, although aquatic fossils are still generally considered rare in amber (e.g. Yu et al. 2019) there are in fact quite numerous examples of these, including clear examples of megalopteran larvae (e.g. Wichard et al. 2009), making the finding of these in Myanmar amber not unlikely.

\section{Identity of the Foulden Maar specimen: new morphotype 1}

We can interpret the specimen as a larval form of Megaloptera based on the overall morphology and presence of lateral structures resembling gills, best preserved on abdomen segment 4 (i.e. Fig. 3A-E). Also larvae of some representatives of Coleoptera (e.g. Gyrinidae) do have similar structures. These share with megalopterans, and the fossil, forward projecting (prognathous) mouthparts.

The fossil specimen, however, is in its overall morphology very different from any extant or fossil aquatic larval representatives of Coleoptera, especially in the shape of the trunk; therefore it seems more likely that the fossil is a larva of Megaloptera. It remains hard to interpret a possible closer relationship of the fossil within Megaloptera, due to the relatively poor preservation of the specimen. The short pronotum could indicate the affinity with the Sialidae larvae, rather than Corydalidae (New \& Theischinger 1993). While the only extant representative of Megaloptera currently inhabiting New Zealand is Archichauliodes diversus Walker, 1853 (Hamilton 1940), it is possible that Sialidae inhabited New Zealand in the past, as they still live in Australia (Theischinger 1983). It is difficult to interpret if the occurrence of this specimen in a lentic environment, as assumed for the Foulden Maar, 

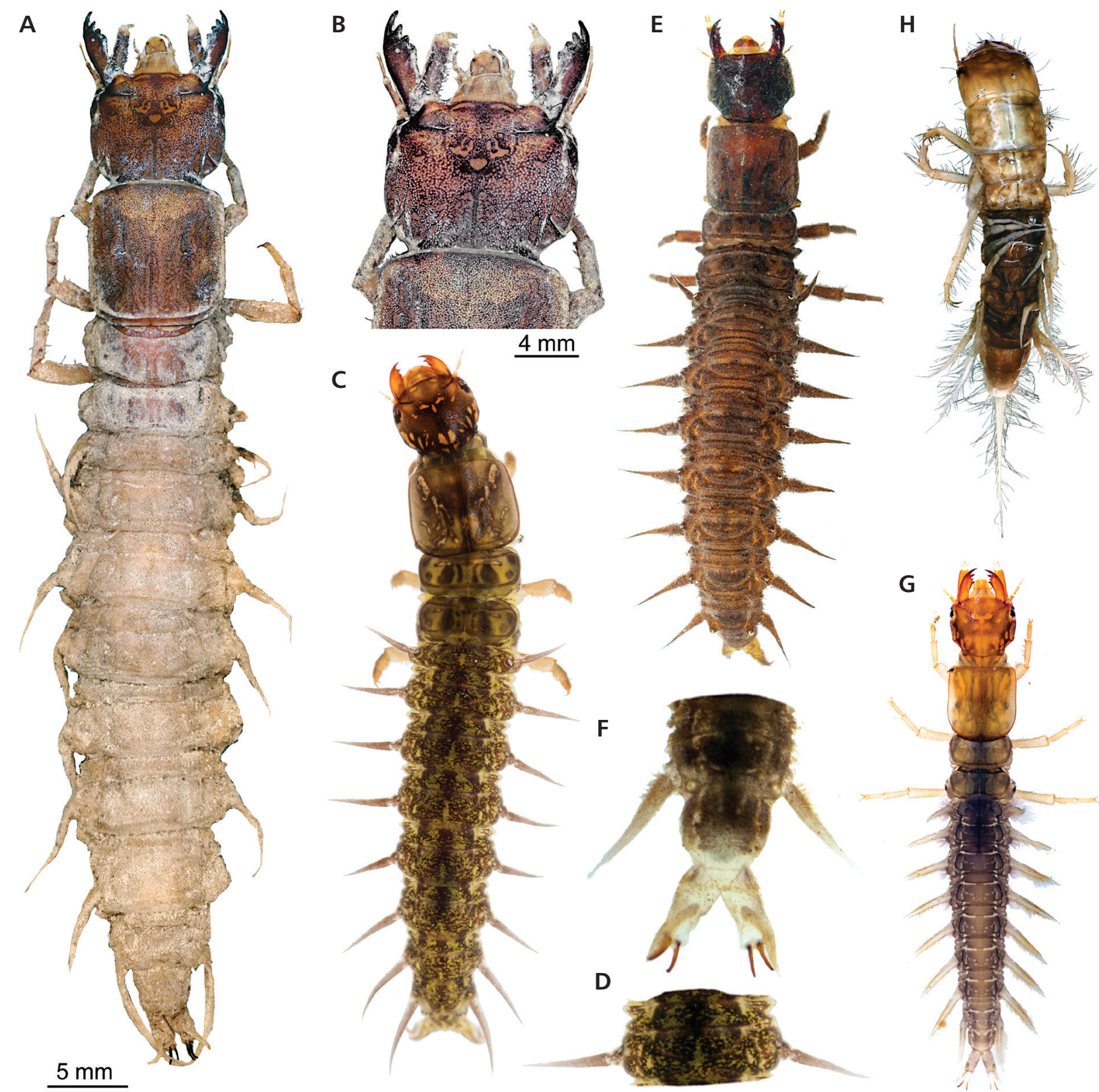

Figure 10. Diversity of extant megalopteran larvae. - A, B - Corydalus Latreille, 1802, larva from Ecuador (Zoological State Collection, ZSM, München); B - head capsule dorsally. C , D - Taeniochauliodes attenuates Esben-Petersen, 1924, larva, scale not available, photograph by Ben Price; D - single abdomen segment 3. $•$ E, F - Madachauliodes Paulian, 1951, larva from Madagascar, scale not available, photograph by Ben Price; F - rear end of the abdomen, scale not available, photograph by Ben Price. $\bullet \mathrm{G}-$ Chloroniella peringueyi Esben-Petersen, 1924, larva from South Africa, scale not available, photograph by Ben Price. $• \mathrm{H}$ - Sialis sp. Latreille, 1803, larva, from H.J. Andrews, experimental forest, OR, USA.

indicates that fossil New Zealand megalopterans were lake dwellers, in contrast to stream-living Archichauliodes diversus (Hamilton 1940).

\section{Identity of the Green River specimen: new morphotype 2}

We can interpret the specimen as a possible larval form of Megaloptera based on several characters. The locomo- tory appendages (legs) have four prominent elements possibly representing coxa, femur, tibia and an undivided tarsus, as can be seen from several legs. We can assume that the trochanter is not well discernible (Beutel et al. 2013). Such a leg subdivision is characteristic for some primarily wingless representatives of Insecta or larval forms of Holometabola. The dense setae on the legs suggest an aquatic lifestyle and hence increase the likelihood of being a holometabolan larva. The posterior trunk (abdomen) is subdivided into ten visible units (of which 
the anterior nine should represent true segments, unit 10 most likely represents conjoined segments $10+11$ ). Several trunk segments bear laterally elongated structures. We interpret these as remnants of lateral gills, which characterise larvae of Megaloptera (e.g. Fig. 10A-H). Within Megaloptera, the specimen can be interpreted as a representative of Sialidae based on the presence of a single posterior elongation, which is broken off in the fossil, but its proximal part is still apparent. The structure strongly resembles (in structure and position) the unpaired terminal structures ("terminal filament") of larvae of Sialidae (Heckman 2017).

This larva potentially represents the first record of the group Megaloptera from the Green River Formation, providing some additional information about the overall original environment of this Lagerstätte. It is possible that a specimen reported by Dayvault et al. (1995: fig. 34) represents an adult of the group Sialidae.

\section{Identity of specimens from amber: new morphotype 3}

We can interpret this specimen as a larva of Megaloptera based on its specific combination of characters. The locomotory appendages (legs) have four prominent elements (coxa, femur, tibia and non-subdivided tarsus), the coxa is especially elongated; the posterior trunk (abdomen) segments, at least seven, very likely eight, bear lateral gills, with dense setae, suggested autapomorphy of Megaloptera (Beutel et al. 2013). Unfortunately, the trunk end is not inside the amber piece and therefore missing. The trunk end is highly informative for identifying representatives of megalopterans and also its ingroups. It can therefore not be entirely excluded that the specimen is a megalopteran-like larva of a closely related lineage.

Within Megaloptera, the specimen resembles larvae of Sialidae in bearing lateral gills on abdomen segments $1-7$, in contrast to larvae of Corydalidae which have eight pairs of gills (Beutel \& Friedrich 2008, Cover \& Bogan 2015, Heckman 2017). Additionally, gills of the abdomen are bearing a lot of hairs, similar to those of Sialidae and not Corydalidae (New \& Theischinger 1993). It is difficult to make further reaching interpretations, as many important diagnostic characters are on the trunk end, which is not preserved (Fig. 4A, B). The specimen is, however, distinct from many larvae of Corydalinae due to the absence of a basal tuft on the lateral gills (Fig. 4A, B). The specimen does not seems to be related to the only megalopteran previously known from Myanmar amber, which is a representative of Sialidae, Haplosialodes liui Huang et al., 2016. It is notable that lateral gills of this specimen are covered with dense setae, which in many species of Corydalidae is a characteristic of an early instar. The relatively small size of this specimen (in the $\mathrm{mm}$ range) is also indicative of a relatively young larval stage (probably larval stage 2-4).

\section{Identity of specimens from amber: new morphotype 4}

While the specimen resembles Megaloptera in general habitus, it is quite possible that it is just superficially resembling a representative of the group. The penultimate element of the antennae bears a prominent sensillum which is digitiform and therefore differs from the sensilla at the penultimate flagellomere of the antenna - an autapomorphy of Megaloptera (Fig. 7C; Beutel et al. 2013). As in the other specimens, the locomotory appendages (legs) have four prominent elements (coxa, femur, tibia and nonsubdivided tarsus); posterior trunk (abdomen) segments bear lateral gills; these appear to have visible articulations, or at least constrictions (Figs 7,8), similar to the gills of larvae of Indosialis and Taeniochauliodes (Liu et al. 2013).

The larvae bear some superficial resemblance to those of Chauliodinae, e.g. those of Chauliodes, Madachauliodes, Taeniochauliodes, in lacking basal tufts of setae next to the lateral gills (Baker \& Neunzig 1968). However, the lateral processes of this new morphotype seem to be more rigid and sitting more dorsally than in the known larvae of Megaloptera. Also here one could argue that these are megalopteran-like larvae, e.g. of beetles. Given the unusual position of the lateral gill-like processes and general shape of the body, we must concede, that the specimen might be a representative of the unknown group of the Coleoptera. Yet, we also don't see such possibility as a problem, as the main goal of this contribution is to highlight the presence of the fossils reminiscent to Megaloptera in the fossil record.

All larvae are very small, and their general body proportions suggest that they represent larval instars one or two (Baker \& Neunzig 1968). It is notable that one of the larvae (SNSB-BSPG 2021 XII 6) is extremely small (ca. $300 \mu \mathrm{m}$ ), which is best compatible with it being an instar one larva (Fig. 8C).

Specimen PED 0335 has a small thread of bead-like structures, possibly individual cells of Cyanobacteria attached to its posterior trunk (Fig. 7E). The presence of these possible prokaryotes on the specimen further supports a connection of the larvae with an aquatic environment.

\section{Taphonomic factors of the seeming scarceness of the fossil record of megalopteran larvae}

We have summarised the entire known fossil record of megalopteran larvae (and megalopteran-like larvae), 
including several new specimens reported herein. Fossils of megalopteran larvae still appear to be rather scarce.

One possible cause of the apparent scarceness of megalopteran larvae in the fossil record is a generally narrow taphonomic window for the preservation of benthic freshwater organisms especially in running waters (Rasnitsyn \& Quicke 2002). Aquatic larvae of Insecta living in low-energy deposition environments, such as lakes, have much higher chances to be preserved. Even organisms in the medium- to high-energy transitional zones, such as estuaries or coastal lagoons, are much more likely preserved than organisms inhabiting rivers (Rasnitsyn \& Quicke 2002). This is well illustrated by the continuous presence of two ingroups of Insecta with aquatic larvae in Jurassic and Lower Cretaceous deposits (Kalugina 1986) that were abundant in lakes: larvae of stoneflies (Plecoptera) and certain non-biting midges (Chironomidae: Podonominae). By the middle of the Cretaceous, these larvae seem to have changed their habitats into streams, due to a number of factors, one of them being the angiosperm diversification (Grimaldi \& Engel 2005). Also, modern counterparts of stonefly and non-biting midge larvae are found in streams at present. After their habitat changed into running waters, the larvae of both groups virtually disappeared from the fossil record.

Many megalopteran larvae, at least those with known biologies, are living in running waters, though some, such as larvae of the group Chauliodes, inhabit predominantly stagnant waters. If we assume that the majority of megalopteran larvae in the past also favoured river or stream environments, this makes the relatively low abundance of megalopteran larvae in the fossil record not surprising.

Taking into account how scarce the fossil record of megalopteran larvae in general is, it is quite surprising that almost $40 \%$ of the records are from amber. Wichard et al. (2009) described a range of possible mechanisms for aquatic organisms to be entrapped in amber (see also discussion in Schädel et al. 2020). Still, we need to consider that there are two notable phases in the life of a megalopteran larva when entrapment in amber outside of the water can occur (Cover \& Bogan 2015). The first one takes place right after hatching from the egg, which we assume to have occurred in the past as in modern relatives, i.e., deposited by the mother in riverbank (riparian) vegetation (Evans 1972). It is quite possible that some of our specimens, namely those of the new morphotype 3, are stage 1 larvae. These could have been trapped on the way from the hatching site to the river, even though this is a quite short distance.

A second possibility for the larvae to be entrapped on land occurs when megalopteran larvae are leaving the water to build their pupation chamber (Evans 1972, Cover \& Bogan 2015). Additionally, modern larvae of
Corydalidae are capable of burrowing into the riverbed in order to survive the drought in the intermittent rivers (Cover \& Bogan 2015). Such larvae burying themselves can also be potentially caught by a flow of amber into the dry riverbed. This is particularly likely as massive resin production in trees might be stimulated by a water-stress situation such as a drought (Seyfullah et al. 2018).

\section{Unusual megalopteran larvae}

It is interesting to note that the few known fossil larvae of Megaloptera mostly resemble their modern day counterparts. If we compare this aspect in the possible sister groups of Megaloptera, Neuroptera and Raphidioptera, we find that the fossil record of their larvae has provided four basic types of larvae: (a) fossil larvae strongly resembling modern specimens (Perrichot \& Engel 2007; Wang et al. 2016; Badano et al. 2018, Haug et al. 2018, 2020a, d; Herrera-Flórez et al. 2020; Pérez-de la Fuente et al. 2020); (b) fossil larvae with "old morphologies"; these often have a mixture of plesiomorphies, i.e. ancestral characters, but already some specialisations of their modern counterparts (Badano et al. 2018); (c) fossil larvae with rather aberrant, experimental-appearing morphologies that are a mixture of characters known from different modern lineages (Haug et al. 2019a); and (d) fossil larvae with rather aberrant, experimental-appearing morphologies that are different from modern lineages in the presence of otherwise unseen characters (Engel 2002; Pérez-de la Fuente et al. 2012, 2016, 2018, 2019; Liu et al. 2016, 2018; Haug et al. 2019b, c, 2020e, f).

Do we find a similar pattern in Megaloptera? The Jurassic larva reported by Ponomarenko (2012) possesses eight pairs of gills on the abdomen and a short posterior protrusion (generally termed 'terminal filament'). This larva can be considered a fossil larva retaining old morphologies. It is best interpreted as an early representative of the group Sialidae. Modern and other fossil larvae of this group have only seven pairs of gills and a very elongate posterior protrusion (terminal filament). The larva is not only exceptional in representing a type of intermediary morphology, but it is also unusual in possessing quite long locomotory appendages (legs).

The new larvae from Myanmar amber may also retain some plesiomorphies and therefore look not exactly similar to their modern counterparts. Still, the overall appearance does not deviate drastically from the modern larvae, they hence appear rather "normal". Does this mean there are no unusual fossil larvae of Megaloptera? Could there be stronger constraints for the morphology of megalopteran larvae?

Engel et al. (2018) have noted that modern representatives of Neuropterida (Neuroptera, Megaloptera, 
Raphidioptera) are on the one hand a relic group, yet on the other hand also highly derived, with their initial diversification probably having taken place during the Devonian and Carboniferous. It is quite possible that the larvae of this "experimental stage" of diversification within Neuropterida simply did not fit the taphonomic window, and most of them did not get preserved in the fossil record. Another possibility is that we are simply not recognising unusual megalopteran larvae as such. In particular, could specimens like Kargalarva permosialis or Srokalarva berthei represent this "experimental stage" in the evolution of Megaloptera?

Probably we will never be able to answer this question with certainty. Yet, a prudent attention to larvae, in particular strange looking "beetle larvae" in fossil resins, will bring more fossil records of megalopteran larvae into light and allow us to better understand the evolution of this fascinating group of Insecta.

\section{Acknowledgements}

This project was kindly supported by the Volkswagen Foundation in the frame of a Lichtenberg Professorship (awarded to J.T. Haug) and by the German Research Foundation (DFG HA 6300/6-1 to J.T. Haug and project 429296833 awarded to U. Kaulfuss). J. Matthias Starck, Munich is thanked for long-term support. We thank all people for providing free software. We are grateful to Ben Price (London Natural History Museum) for providing the images of living megalopteran larvae, to Jonas Damzen (amberinclusions.eu) for images of more specimens in amber, and to all other people who provided images for this study. This is LEON publication \#16.

\section{References}

Ansorge, J. 2001. Dobbertinia reticulata Handlirsch 1920 from the Lower Jurassic of Dobbertin (Mecklenburg/Germany) the oldest representative of Sialidae (Megaloptera). Neues Jahrbuch für Geologie und Paläontologie, Monatshefte 9, 553-564. DOI 10.1127/njgpm/2001/2001/553

Badano, D., Engel, M.S., Basso, A., Wang, B. \& Cerretti, P. 2018. Diverse Cretaceous larvae reveal the evolutionary and behavioural history of antlions and lacewings. Nature Communications 9(1), 3257. DOI 10.1038/s41467-018-05484-y

BaKer, J.R. \& Neunzig, H.H. 1968. The egg masses, eggs, and first-instar larvae of Eastern North American Corydalidae. Annals of the Entomological Society of America 61, 1181-1187. DOI 10.1093/aesa/61.5.1181

Baranov, V., Hoffeins, C., Hoffeins, H.-W. \& Haug, J.T. 2019a. More than dead males: reconstructing the ontogenetic series of terrestrial non-biting midges from the Eocene amber forest. Bulletin of Geosciences 94, 187-199.

DOI 10.3140/bull.geosci.1739
Baranov, V.A., Schädel, M. \& Haug, J.T. 2019b. Fly palaeoevo-devo: immature stages of bibionomorphan dipterans in Baltic and Bitterfeld amber. PeerJ 7, e 7843.

DOI 10.7717/peerj.7843

Bechly, G. \& Wichard, W. 2008. Damselfly and dragonfly nymphs in Eocene Baltic amber (Insecta: Odonata), with aspects of their palaeobiology. Palaeodiversity 1, 37-73.

Beutel, R.G. \& Friedrich, F. 2008. Comparative study of larval head structures of Megaloptera (Hexapoda). European Journal of Entomology 105, 917-938.

DOI 10.14411/eje.2008.119

Beutel, R.G., Friedrich, F., Yang, X.-K. \& Ge, S.-Q. 2013. Insect Morphology and Phylogeny: A textbook for students of entomology. 385-393 pp. De Gruyter, Berlin, Boston. DOI 10.1515/9783110264043

CAo, C. \& Liu, X. 2013. Description of the final-instarlarva and pupa of Acanthacorydalis orientalis (McLachlan, 1899) (Megaloptera: Corydalidae) with some life history notes. Zootaxa 3691, 145. DOI 10.11646/zootaxa.3691.1.5

Cole, R.D. \& Picard, M.D. 1978. Comparative mineralogy of nearshore and offshore lacustrine lithofacies, Parachute Creek Member of the Green River Formation, Piceance Creek Basin, Colorado, and eastern Uinta Basin, Utah. Geological Society of America Bulletin 89, 1441-1454.

DOI 10.1130/0016-7606(1978)89<1441:CMONAO>2.0.CO;2

Coleman, C.O. 2004. Aquatic amphipods (Crustacea: Amphipoda: Crangonyctidae) in three pieces of Baltic amber. Organisms Diversity \& Evolution 4(1-2), 119-122. DOI 10.1016/j.ode.2004.01.003

Coleman, C.O. 2006. An amphipod of the genus Synurella Wrzesniowski, 1877 (Crustacea, Amphipoda, Crangonyctidae) found in Baltic amber. Organisms Diversity \& Evolution 6(2), 103-108. DOI 10.1016/j.ode.2005.06.002

Coleman, H.O. \& Myers, A.A. 2001. New Amphipoda from Baltic amber. Polskie Archiwum Hydrobiologii 47(3/4), 457-464.

Coope, G.R. 1970. Interpretations of Quaternary Insect Fossils. Annual Review of Entomology 15, 97-121. DOI 10.1146/annurev.en.15.010170.000525

Cover, M.R. \& Bogan, M.T. 2015. Minor Insect Orders, 1059-1072. In Thorp, J.H. \& Rogers, D.C. (eds) Thorp and Covich's Freshwater Invertebrates. Elsevier. DOI 10.1016/B978-0-12-385026-3.00041-3

Cover, M.R. \& Resh, V.H. 2008. Global diversity of dobsonflies, fishflies, and alderflies (Megaloptera; Insecta) and spongillaflies, nevrorthids, and osmylids (Neuroptera; Insecta) in freshwater. Hydrobiologia 595, 409-417. DOI 10.1007/s10750-007-9035-Z

Cruickshank, R.D. \& Ko, K. 2003. Geology of an amber locality in the Hukawng Valley, northern Myanmar. Journal of Asian earth Sciences 21(5), 441-455. DOI 10.1016/S1367-9120(02)00044-5

Dayvault, R.D., Codington, L.A., Kohls, D., Hawes, W.D., Otт, P.M. \& BehnKe, D. 1995. Fossil Insects and Spiders from Three Locations in the Green River Formation of the Piceance Creek Basin, Colorado, 97-115. In GRAND Junction Geological Society (ed.) The Green River Formation in 
Piceance Creek and Eastern Uinta Basins, Field Trip 1995. Grand Junction, CO, USA.

Du, B.J., Chen, R., Li, X.Z., TaO, W.T., Bu, W.J., Xiao, J.H. \& Huang, D.W. 2019. The first amber caridean shrimp from Mexico reveals the ancient adaptation of the Palaemon to the mangrove estuary environment. Scientific Reports 9(1), 1-6. DOI 10.1038/s41598-019-51218-5

Engel, M.S. 2002. The smallest snakefly (Raphidioptera: Mesoraphidiidae): a new species in Cretaceous amber from Myanmar, with a catalog of fossil snakeflies. American Museum Novitates 3363, 1-22.

DOI 10.1206/0003-0082(2002)363<0001:TSSRMA>2.0.CO;2

Engel, M.S., Winterton, S.L. \& Breitkreuz, L.C.V. 2018. Phylogeny and evolution of Neuropterida: Where have wings of lace taken us? Annual Review of Entomology 63, 531-551. DOI 10.1146/annurev-ento-020117-043127

ESBEN-PETERSEN, P. 1924. South African Megaloptera. Annals of the South African Museum 19, 151-158.

Evans, E.D. 1972. A study of the Megaloptera of the Pacific coastal region of the United States. 210 pp. Ph.D. thesis, Oregon State University, Corvallis, Oregon, USA.

Girard, V., Schmidt, A.R., Saint Martin, S., Struwe, S., Perrichot, V., Saint Martin, J.P., Grosheny, D., Bretona, G. \& Neraudeau, D. 2008. Evidence for marine microfossils from amber. Proceedings of the National Academy of Sciences 105(45), 17426-17429. DOI 10.1073/pnas.0804980105

Grande, L. 1984. Paleontology of the Green River Formation, with a review of the fish fauna. $2^{\text {nd }}$ edition. Bulletin of the Geological Survey of Wyoming 63, 1-333.

Grande, L. 2013. The lost world of Fossil Lake: Snapshots from deep time. 425 pp. University of Chicago Press. DOI 10.7208/chicago/9780226922980.001.0001

Grimaldi, D.A. \& Engel, M.S. 2005. Evolution of the insects. 755 pp. Cambridge University Press, Cambridge, New York.

GröHN, C. 2015. Einschlüsse im baltischen Bernstein. 424 pp. Wachholtz Verlag-Murmann Publishers, Fleethörn, Germany.

Gustafson, G.T., Michat, M.C. \& Balke, M. 2020. Burmese amber reveals a new stem lineage of whirligig beetle (Coleoptera: Gyrinidae) based on the larval stage. Zoological Journal of the Linnean Society 189(4), 1232-1248.

DOI 10.1093/zoolinnean/zlz161

Handlirsch, A. 1920. Kapitel 7,117-304. Palaeontologie. In SCHröDER, C. (ed.) Handbuch der. Entomologie, III. G. Fischer, Jena.

Hamilton, A. 1940. The New Zealand Dobson-fly (Archichauliodes diversus Walk.): Life-history and Bionomics. New Zealand Journal of Science and Technology 22(1A), 44-55.

HaUG, J.T. 2020. Why the term "larva" is ambiguous, or what makes a larva? Acta Zoologica 101, 167-188.

DOI 10.1111/azo.12283

HaUG, J.T. \& HAUG, C. 2021. A 100 million-year-old armoured caterpillar supports the early diversification of moths and butterflies. Gondwana Research 93, 101-105.

DOI 10.1016/j.gr.2021.01.009

Haug, J.T., Haug, C., Kutschera, V., Mayer, G., Maas, A., Liebau, S., Castellani, C., Wolfram, U., Clarkson, E.N.K. \& WaloszeK, D. 2011. Autofluorescence imaging, an excel- lent tool for comparative morphology: autofluorescence imaging. Journal of Microscopy 244, 259-272.

DOI 10.1111/j.1365-2818.2011.03534.X

Haug, J.T., Müller, C.H.G. \& Sombke, A. 2013. A centipede nymph in Baltic amber and a new approach to document amber fossils. Organisms Diversity \& Evolution 13, 425-432. DOI 10.1007/s13127-013-0129-3

Haug, J.T., Labandeira, C.C., Santiago-Blay, J.A., Haug, C. \& Brown, S. 2015. Life habits, hox genes, and affinities of a 311 million-year-old holometabolan larva. BMC Evolutionary Biology 15(1), 1-10. DOI 10.1186/s12862-015-0428-8

Haug, J.T., Müller, P. \& Haug, C. 2018. The ride of the parasite: a 100-million-year old mantis lacewing larva captured while mounting its spider host. Zoological Letters 4, 31.

DOI 10.1186/s40851-018-0116-9

Haug, C., Herrera-Flórez, A.F., Müller, P. \& Haug, J.T. 2019a. Cretaceous chimera-an unusual 100-million-year old neuropteran larva from the "experimental phase" of insect evolution. Palaeodiversity 12(1), 1-11.

DOI 10.18476/pale.v12.a1

Haug, J.T., Müller, P. \& Haug, C. 2019b. A 100-millionyear old predator: a fossil neuropteran larva with unusually elongated mouthparts. Zoological Letters 5(1), 29.

DOI 10.1186/s40851-019-0144-0

Haug, J.T., Müller, P. \& Haug, C. 2019c. A 100-million-year old slim insectan predator with massive venom-injecting stylets - a new type of neuropteran larva from Burmese amber. Bulletin of Geosciences 94, 431-440.

DOI 10.3140/bull.geosci.1753

Haug, J.T., Baranov, V., Schädel, M., Müller, P., Gröhn, P. \& HaUg, C. 2020a. Challenges for understanding lacewings: how to deal with the incomplete data from extant and fossil larvae of Nevrorthidae? (Neuroptera). Fragmenta entomologica 52, 137-167. DOI 10.4081/fe.2020.472

Haug, J.T., Schädel, M., Baranov, V.A. \& Haug, C. 2020 b. An unusual 100-million-year old holometabolan larva with a piercing mouth cone. PeerJ 8, e8661.

DOI 10.7717 peerj. 8661

Haug, J.T. et al. 2020c. Comment on the letter of the Society of Vertebrate Paleontology (SVP) dated April 21, 2020 regarding "Fossils from conflict zones and reproducibility of fossil-based scientific data": Myanmar amber. PalZ 94, 431-437. DOI 10.1007/s12542-020-00524-9

Haug, J.T., Müller, P. \& Haug, C. 2020e. A 100 million-yearold snake-fly larva with an unusually large antenna. Bulletin of Geosciences 95, 167-177.

DOI 10.3140/bull.geosci.1757

Haug, J.T., Pazinato, P.G., Haug, G.T. \& Haug, C. 2020f. Yet another unusual new type of lacewing larva preserved in 100-million-year old amber from Myanmar. Rivista Italiana di Paleontologia e Stratigrafia 126, 821-832.

Heard, R.W., De Lourdes Serrano-Sánchez, M. \& Vega, F.J. 2018. Early Miocene Tanaidacea (Crustacea: Malacostraca) preserved in amber from Chiapas, Mexico, with the preliminary descriptions of new taxa. Neues Jahrbuch für Geologie und Paläontologie, Abhandlungen 288(1), 107-120.

DOI 10.1127/njgpa/2018/0726 
Heckman, C.W. 2017. Neuroptera (Including Megaloptera), Encyclopedia of South American Aquatic Insects. 75-119 pp. Springer International Publishing, Cham.

DOI 10.1007/978-3-319-35125-4_3

Herrera-Flórez, A.F., Braig, F., Haug, C., Neumann, C., Wunderlich, J., Hörnig, M.K. \& Haug, J.T. 2020. Identifying the oldest larva of a myrmeleontiformian lacewing a morphometric approach. Acta Palaeontologica Polonica 65, 235-250. DOI 10.4202/app.00662.2019

Hörnig, M., Sombke, A., Haug, C., Harzsch, S. \& Haug, J. 2016. What nymphal morphology can tell us about parental investment - a group of cockroach hatchlings in Baltic amber documented by a multi-method approach. Palaeontologia Electronica 19.1.6A, 1-20. DOI 10.26879/571

Huang, D., Azar, D., Engel, M.S., Cai, C., Garrouste, R. \& Nel, A. 2016. A new genus of alderflies (Megaloptera: Sialidae) in Upper Cretaceous Burmese amber. Cretaceous Research 64, 7-11. DOI 10.1016/j.cretres.2016.03.012

Huber, P., McDonald, N.G. \& Olsen, P.E. 2003. Early Jurassic Insects from the Newark Supergroup, Northeastern United States, 206-223. In LeTourneau, P.M. \& Olsen, P. E. (eds) The Great Rift Valleys of Pangea in Eastern North America, Volume 2. Sedimentology, Stratigraphy, and Paleontology.

Huys, R., Suárez-Morales, E., De Lourdes Serrano-Sánchez, M., Centeno-García, E. \& Vega, F.J. 2016. Early Miocene amber inclusions from Mexico reveal antiquity of mangroveassociated copepods. Scientific Reports 6(1), 1-12.

DOI 10.1038/srep34872

Illies, J. 1967. Megaloptera and Plecoptera (Ins.) aus den jungpliozänen Süßwassermergeln von Willershausen. Berichte der Naturhistorischen Gesellschaft Hannover 111, 47-55.

JażDŻEwski, K. \& Kupryjanowicz, J. 2010. One more fossil niphargid (Malacostraca: Amphipoda) from Baltic amber. Journal of Crustacean Biology 30(3), 413-416. DOI 10.1651/09-3259.1

JażDżewski, K., Grabowski, M. \& Kupryjanowicz, J. 2014. Further records of Amphipoda from Baltic Eocene amber with first evidence of prae-copulatory behaviour in a fossil amphipod and remarks on the taxonomic position of Palaeogammarus Zaddach, 1864. Zootaxa 3765(5), 401-417. DOI 10.11646/zootaxa.3765.5.1

Kalugina, N.S. 1986. Infraorders Tipulomorpha and Culicomorpha, 121-125. In Tatarinov, L.P., Luwsandansan, B., Afanasyeva, G.A., Barsbold, R., Morosowa, I.P., Novitskaya, L.I., Reshetov, V.Yu., Rozanov, A.Yu., Sysoev, V.A., Trofimov, B.A. \& Rasnitsyn, A.P. (eds) Insects in the Early Cretaceous Ecosystems of the Western Mongolia. Nauka, Moscow. [in Russian]

Kaulfuss, U. 2017. Crater stratigraphy and the post-eruptive evolution of Foulden Maar, southern New Zealand. New Zealand Journal of Geology and Geophysics 60(4), 410-432. DOI 10.1080/00288306.2017.1365733

Kukalova-Peck, J. \& Willmann, R. 1990. Lower Permian "mecopteroid-like" insects from central Europe (Insecta, Endopterygota). Canadian Journal of Earth Sciences 27(3), 459-468. DOI 10.1139/e90-041
LAtreille, P.A. 1802. Histoire naturelle générale et particulière des Crustacés et des insectes (Vol. 10). 445 pp. L'Imprimerie de F. Dufart, Paris.

Latreille, P.A. 1803. Histoire naturelle générale et particulière des Crustacés et des insectes (Vol. 5). 406 pp. L'Imprimerie de F. Dufart, Paris.

Lee, D.E., Kaulfuss, U., Conran, J.G., Bannister, J.M. \& LindQVIST, J.K. 2016. Biodiversity and palaeoecology of Foulden Maar: an early Miocene Konservat-Lagerstätte deposit in southern New Zealand. Alcheringa 40(4), 525-541. DOI 10.1080/03115518.2016.1206321

LindQVist, J.K. \& LEE, D.E. 2009. High-frequency paleoclimate signals from Foulden Maar, Waipiata Volcanic Field, southern New Zealand: An early Miocene varved lacustrine diatomite deposit. Sedimentary Geology 222, 98-110. DOI 10.1016/j.sedgeo.2009.07.009

Liu, X., Wang, Y., Shin, C., Ren, D. \& YAnG, D. 2012. Early Evolution and Historical Biogeography of Fishflies (Megaloptera: Chauliodinae): Implications from a Phylogeny Combining Fossil and Extant Taxa. PLoS ONE 7, e40345. DOI 10.1371/journal.pone.0040345

Liu, X., Price, B., Hayashi, F., De Moor, F. \& Yang, D. 2013. Systematic revision reveals underestimated diversity of the South African endemic fishfly genus Taeniochauliodes Esben-Petersen (Megaloptera: Corydalidae). Systematic Entomology 38, 543-560. DOI 10.1111/syen.12009

Liu, X., Zhang, W., Winterton, S.L., Breitkreuz, L.C. \& Engel, M.S. 2016. Early morphological specialization for insectspider associations in Mesozoic lacewings. Current Biology 26(12), 1590-1594. DOI 10.1016/j.cub.2016.04.039

Liu, X., Shi, G., XiA, F., Lu, X., Wang, B. \& Engel, M.S. 2018. Liverwort mimesis in a Cretaceous lacewing larva. Current Biology 28(9), 1475-1481. DOI 10.1016/j.cub.2018.03.060

Mildenhall, D.C., Kennedy, E.M., Lee, D.E., Kaulfuss, U., Bannister, J.M., Fox, B. \& Conran, J.G. 2014. Palynology of the early Miocene Foulden Maar, Otago, New Zealand: Diversity following destruction. Review of Palaeobotany and Palynology 204, 27-42. DOI 10.1016/j.revpalbo.2014.02.003

Nel, A. 1991. Nouveaux insectes neuropteroïdes fossiles de l'Oligocene de France (Neuroptera et Megaloptera). Bulletin du Museum National d'Histoire Naturelle Serie C Geologie 12, 327-349.

Nel, A., Roques, P., Nel, P., Prokin, A.A., Bourgoin, T., Prokop, J., Szwedo, J., Azar, D., Desutter-Grandcolas, L., Wappler, T., Garrouste, R., Coty, D., Huang, D., Engel, M.S. \& KirejtshuK, A.G. 2013. The earliest known holometabolous insects. Nature 503(7475), 257-261. DOI 10.1038/nature12629

New, T.R. \& Theischinger, G. 1993. Handbook of Zoology, Volume IV Arthropoda: Insecta, Part 33 Megaloptera. 102 pp. Walter de Gruyter, Berlin.

Paulian, R. 1951. Faunes des eaux douces de Madagascar. I. Plécoptères et Mégaloptères. Memoires de l'Institut Scientifique de Madagascar, Series A 6, 53-61.

Pérez-de la Fuente, R., Delclòs, X., Peñalver, E., Speranza, M., Wierzchos, J., Ascaso, C. \& Engel, M.S. 2012. Early evolution and ecology of camouflage in insects. Proceedings 
of the National Academy of Sciences 109(52), 21414-21419. DOI 10.1073/pnas.1213775110

Pérez-de la Fuente, R., Delclòs, X., Peñalver, E. \& Engel, M.S. 2016. A defensive behavior and plant-insect interaction in Early Cretaceous amber-the case of the immature lacewing Hallucinochrysa diogenesi. Arthropod Structure \& Development 45(2), 133-139.

DOI 10.1016/j.asd.2015.08.002

Pérez-de la Fuente, R., Peñalver, E., Azar, D. \& Engel, M.S. 2018. A soil-carrying lacewing larva in Early Cretaceous Lebanese amber. Scientific Reports 8(1), 16663. DOI 10.1038/s41598-018-34870-1

Pérez-de la Fuente, R., Engel, M.S., Azar, D. \& Peñalver, E. 2019. The hatching mechanism of 130-million-year-old insects: an association of neonates, egg shells and egg bursters in Lebanese amber. Palaeontology 62(4), 547-559. DOI 10.1111/pala.12414

Pérez-de la Fuente, R., Engel, M.S., Delclòs, X. \& Peñalver, E. 2020. Straight-jawed lacewing larvae (Neuroptera) from Lower Cretaceous Spanish amber, with an account on the known amber diversity of neuropterid immatures. Cretaceous Research 106, 104200. DOI 10.1016/j.cretres.2019.104200

Perrichot, V. \& Engel, M.S. 2007. Early Cretaceous snakefly larvae in amber from Lebanon, Myanmar, and France (Raphidioptera). American Museum Novitates 3598, 1-11. DOI 10.1206/0003-0082(2007)3598[1:ECSLIA]2.0.CO;2

Ponomarenko, A.G. 1976. Corydalidae (Megaloptera) from the Cretaceous of northern Asia. Entomological Review 55, 114-122.

Ponomarenko, A.G. 2012. Supposed alderfly larva (Insecta, Megaloptera) from the Jurassic locality Shar-Teg, southwestern Mongolia. Paleontological Journal 46, 378-382. DOI 10.1134/S0031030112040090

Prokin, A.A., Ponomarenko, A.G. \& Kirejtshuk, A.G. 2019. Description of a larva of Kargalarva permosialis gen. et sp. nov. (Coleoptera: Schizophoromorpha) from the Kargala fossil site. Paleontological Journal 53, 282-286.

DOI 10.1134/S0031030119030110

Prokin, A.A. \& Bashruev, A.S. 2021. Trialarva coburgensis gen. et sp. nov., a remarkable fossil holometabolan larva (Insecta: Coleoptera) from the Triassic of Germany. PalZ, 95(1), 55-60.

DOI 10.1007/s12542-020-00527-6

Rasnitsyn, A.P. \& Quicke, D.L.J. (eds) 2002. History of Insects. 517 pp. Kluwer Academic Publisher, New York, Boston, Dordrecht, London, Moscow.

Ross, A.J. 2019. Burmese (Myanmar) amber checklist and bibliography 2018. Palaeoentomology 2, 22-84.

DOI 10.11646/palaeoentomology.2.1.5

Sánchez-García, A., Peñalver, E., Pérez-de la Fuente, R. \& Delclòs, X. 2015. A rich and diverse tanaidomorphan (Crustacea: Tanaidacea) assemblage associated with Early Cretaceous resin-producing forests in North Iberia: palaeobiological implications. Journal of Systematic Palaeontology 13(8), 645-676. DOI 10.1080/14772019.2014.944946

Schädel, M., Perrichot, V. \& Haug, J.T. 2019. Exceptionally preserved cryptoniscium larvae - morphological details of rare isopod crustaceans from French Cretaceous Vendean amber. Palaeontologia Electronica 22(3.71), 1-46.

DOI 10.26879/977

Schädel, M., Müller, P., \& Haug, J.T. 2020. Two remarkable fossil insect larvae from Burmese amber suggest the presence of a terminal filum in the direct stem lineage of dragonflies and damselflies (Odonata). Rivista Italiana di Paleontologia e Stratigrafia 126(1), 13-35.

Schädel, M., Hörnig, M.K., HyžnÝ, M. \& Haug, J.T. 2021a. Mass occurrence of small isopodan crustaceans in 100-million-year-old amber: an extraordinary view on behaviour of extinct organisms. PalZ 95, 429-445.

DOI 10.1007/s12542-021-00564-9

SCHÄDEl, M., HyŽNÝ, M. \& HAUG, J.T. 2021b. Ontogenetic development captured in amber - the first record of aquatic representatives of Isopoda in Cretaceous amber from Myanmar. Nauplius 29, e2021003.

DOI 10.1590/2358-2936e2021003

Serrano-Sánchez, M., Hegna, T.A., Schahf, P., Pérez, L., Centeno-García, E. \& Vega, F.J. 2015. The aquatic and semiaquatic biota in Miocene amber from the Campo La Granja mine (Chiapas, Mexico): Paleoenvironmental implications. Journal of South American Earth Sciences 62, 243-256. DOI 10.1016/j.jsames.2015.06.007

Serrano-Sánchez, M.L., Nagler, C., Haug, C., Haug, J.T., Centeno-García, E. \& Vega, F.J. 2016. The first fossil record of larval stages of parasitic isopods: cryptoniscus larvae preserved in Miocene amber. Neues Jahrbuch für Geologie und Paläontologie, Abhandlungen 279(1), 97-106.

DOI 10.1127/njgpa/2016/0543

Seyfullah, L.J., Roghi, G., Corso, J.D. \& Schmidt, A.R. 2018. The Carnian Pluvial Episode and the first global appearance of amber. Journal of the Geological Society 175, 1012-1018. DOI 10.1144/jgs2017-143

Sharov, A.G. 1953. The first find of a Permian megalopteran larva from Kargala. Dokladi Akademii Nauk SSSR 89, 731-732.

Shear, W.A. \& Kukalová-Peck, J. 1990. The ecology of Paleozoic terrestrial arthropods: the fossil evidence. Canadian Journal of Zoology 68(9), 1807-1834. DOI 10.1139/z90-262

Sroka, P., Staniczek, A.H. \& KondratiefF, B.C. 2018. 'Rolling' stoneflies (Insecta: Plecoptera) from mid-Cretaceous Burmese amber. PeerJ 6, e5354. DOI 10.7717/peerj.5354

Stewart, K.W., Friday, G.P. \& Rhame, R.E. 1973. Food habits of hellgrammite larvae, Corydalus cornutus (Megaloptera: Corydalidae), in the Brazos River, Texas. Annals of the Entomological Society of America 66, 959-963.

DOI 10.1093/aesa/66.5.959

Swanson, D.R., Heads, S.W., TaYlor, S.J. \& Wang, Y. 2021. A new remarkably preserved fossil assassin bug (Insecta, Heteroptera, Reduviidae) from the Eocene Green River Formation of Colorado. Papers in Palaeontology, early view, 1-20. DOI 10.1002/spp2.1349

Theischinger, G. 1983. The adults of the Australian Megaloptera. Aquatic Insects 5(2), 77-98.

DOI 10.1080/01650428309361130

Van der Weele, H.W. 1910. On Panorpata and Planipennia 
collected in western Java. Notes from the Leyden Museum 32(4), 199-202.

WaLKer, F. 1853. List of specimens of Neuropterous insects in the collection of the British Museum. Part III, 501-529. In WALKER, F. (ed.) List of specimens of Neuropterous insects in the collection of the British Museum. Part III.

WANG, B. \& Zhang, H. 2010. Earliest Evidence of Fishflies (Megaloptera: Corydalidae): An exquisitely preserved larva from the Middle Jurassic of China. Journal of Paleontology 84, 774-780. DOI 10.1017/S0022336000058480

Wang, B., Xia, F., Engel, M.S., Perrichot, V., Shi, G., Zhang, H., Chen, J., Jarzembowski, E.A., Wappler, T. \& Rust, J. 2016. Debris-carrying camouflage among diverse lineages of Cretaceous insects. Science Advances 2(6), e1501918. DOI 10.1126/sciadv. 1501918

Wang, Y., Liu, X., Garzón-Orduña, I.J., Winterton, S.L., YAN, Y., Aspöck, U. \& YAng, D. 2017. Mitochondrial phylogenomics illuminates the evolutionary history of Neuropterida. Cladistics 33(6), 617-636.

DOI 10.1111/cla.12186

WeIDNER, H. 1958. Einige interessante Insektenlarven aus der Bemsteininklusensammlung des Geologischen Staatsinstituts Hamburg (Odonata, Coleoptera, Megaloptera, Planipennia). Mitteilungen aus dem Geologisch-Paläontologischen Institut (GPI) der Universität Hamburg 27, 50-68.

Weitschat, W. \& Wichard, W. 1998. Atlas der Tiere und Pflanzen im Baltischen Bernstein. 256 pp. Verlag Dr. Friedrich Pfeil, Munich, Germany.

Weitschat, W. \& Wichard, W. 2002. Atlas of Plants and Animals in Baltic Amber. 256 pp. Verlag Dr. Friedrich Pfeil, Munich, Germany.

Weitschat, W. \& Wichard, W. 2010. Baltic amber, 80-115. In Penney, D. (ed.) Biodiversity of Fossils in Amber from the Major World Deposits. Siri Scientific Press, Manchester, UK.

WichARD, W. 2005. Wasserinsekten im Baltischen Bernstein: Zeitzeugen eines alttertiären Waldes. Biologie in unserer Zeit 35, 83-89. DOI 10.1002/biuz.200410276

Wichard, W. 2017. Family Nevrorthidae (Insecta, Neuroptera) in mid-Cretaceous Burmese amber. Palaeodiversity 10(1), 1-5. DOI 10.18476/pale.v10.a1

Wichard, W. \& Engel, M.S. 2006. A new alderfly in Baltic amber (Megaloptera: Sialidae). American Museum Novitates 35(13), 1-9.

DOI 10.1206/0003-0082(2006)3513[1:ANAIBA]2.0.CO;2
Wichard, W. \& Weitschat, W. 1996. Wasserinsekten im Bernstein: eine paläobiologische Studie (Vol. 4). 121 pp. Löbbecke-Museum und Aquazoo, Düsseldorf.

Wichard, W. \& Weitschat, W. 2004. Im Bernsteinwald. 168 pp. Gerstenberg Verlag, Hildesheim.

Wichard, W., Gröhn, C. \& Seredszus, F. 2009. Aquatic insects in Baltic amber: Wasserinsekten im Baltischen Bernstein. 336 pp. Verlag Kessel, Remagen-Oberwinter, Germany.

WiLLmann, R. 1998. Advances and problems in insect phylogeny, 269-279. In Fortey, R.A. \& Thomas, R.H. (eds) Arthropod relationships. Springer, Dordrecht.

DOI 10.1007/978-94-011-4904-4_20

Winterton, S.L., Hardy, N.B. \& Wiegmann, B.M. 2010. On wings of lace: phylogeny and Bayesian divergence time estimates of Neuropterida (Insecta) based on morphological and molecular data. Systematic Entomology 35, 349-378. DOI 10.1111/j.1365-3113.2010.00521.x

Winterton, S.L., Lemmon, A.R., Gillung, J.P., Garzon, I.J., Badano, D., Bakkes, D.K. \& Oswald, J.D. 2018. Evolution of lacewings and allied orders using anchored phylogenomics (Neuroptera, Megaloptera, Raphidioptera). Systematic Entomology 43(2), 330-354.

DOI 10.1111/syen. 12278

XIA, F., YAng, G., Zhang, Q., Shi, G. \& Wang, B. 2015. Amber: Life through Time and Space. 197 pp. Science Press, Beijing.

Yu, T., Kelly, R., Mu, L., Ross, A., Kennedy, J., Broly, P., Xia, F., Zhang, H., Wang, B. \& Dilcher, D. 2019. An ammonite trapped in Burmese amber. Proceedings of the National Academy of Sciences 116(23), 11345-11350. DOI 10.1073/pnas.1821292116

Zhao, X., Zhao, X., Wang, B., Jarzembowski, E., Fang, Y. \& Chen, L. 2019. The first corydalid larva (Megaloptera: Corydalidae) with gut-contents from the Early Cretaceous Jehol biota of northeastern China. Cretaceous Research 100, 46-50. DOI 10.1016/j.cretres.2019.03.015

ZhaO, Y., Zhang, H. \& Zhang, Y. 2017. Complete mitochondrial genome of Neochauliodes parasparsus (Megaloptera: Corydalidae) with phylogenetic consideration. Biochemical Systematics and Ecology 70, 192-199. DOI 10.1016/j.bse.2016.12.002

Zhao, X., Zhao, X., Jarzembowski, E.A. \& Wang, B. 2019. The first whirligig beetle larva from mid-Cretaceous Burmese amber (Coleoptera: Adephaga: Gyrinidae). Cretaceous Research 99, 41-45. DOI 10.1016/j.cretres.2019.02.015 